$1-1-2020$

\title{
Regulating Impartiality in Agency Adjudication
}

Kent H. Barnett

Associate Dean for Academic Affairs \& J. Alton Hosch Professor of Law University of Georgia School of Law, khbarn@uga.edu

University of Georgia School of Law

Research Paper Series

Paper No. 2019-37

DSPRN

\section{Repository Citation}

Kent H. Barnett, Regulating Impartiality in Agency Adjudication , 69 Duke L.J. 1695 (2020),

Available at: https://digitalcommons.law.uga.edu/fac_artchop/1414

This Article is brought to you for free and open access by the Faculty Scholarship at Digital Commons @ University of Georgia School of Law. It has been accepted for inclusion in Scholarly Works by an authorized administrator of Digital Commons @ University of Georgia School of Law. Please share how you have benefited from this access For more information, please contact tstriepe@uga.edu. 


\title{
REGULATING IMPARTIALITY IN AGENCY ADJUDICATION
}

\author{
KENT BARNETT $\dagger$
}

\begin{abstract}
Which should prevail-the Take Care Clause of Article II or the Due Process Clause? To Justice Breyer's chagrin, the majorities in Lucia v. SEC and Free Enterprise Fund v. PCAOB expressly declined to resolve whether the U.S. Constitution condones SEC administrative law judges' and other similarly situated agency adjudicators' current statutory protection from at-will removal. The crux of the problem is that, on one hand, senior officials may use at-will removal to pressure agency adjudicators and thereby potentially imperil the impartiality that due process requires. On the other hand, Article II limits Congress's ability to cocoon executive officers, including potentially agency adjudicators, from at-will removal.

This Article argues that the executive branch itself can and should moot or mitigate this constitutional clash. Nothing in Article II prevents the president from issuing executive orders and agencies from promulgating regulations - collectively, what I refer to as "impartiality regulations"-that require good cause for disciplining and removing agency adjudicators, as well as other means of protecting adjudicator impartiality. Indeed, the executive branch has a long-standing yet overlooked practice of using executive orders and regulations for similar purposes. Impartiality regulations are but one form of the executive branch's internal separation of powers. Such self-imposed separation provides a strong theoretical and practical solution for the agency-adjudicator dilemma.
\end{abstract}

\footnotetext{
Copyright (C) 2020 Kent Barnett.

$\dagger \quad$ J. Alton Hosch Associate Professor of Law, University of Georgia School of Law. I appreciate helpful comments from Michael Asimow, Jayme Herschkopf, Linda Jellum, Jonathan Nash (and the Emory law students in his Colloquium Series Workshop), Dick Pierce, Kevin Stack, Chris Walker, Matthew Weiner, David Zaring, and the administrative law judges at the 2019 Annual Federal Administrative Law Judges Conference. I am deeply thankful for the careful and thoughtful editorial assistance from the Duke Law Journal.
} 


\section{TABLE OF CONTENTS}

Introduction 1696

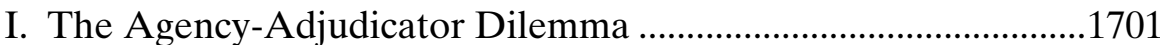

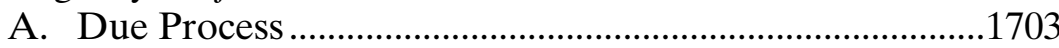

B. The Take Care Clause......................................................1707

C. Avoiding and Resolving the Agency-Adjudicator Dilemma 1711

1. Constitutional Status .......................................................1711

2. Adjudication Function ...................................................1714

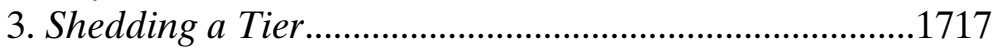

II. Internal Separation of Powers.................................................1720

A. Separation of Powers via Internal Administrative Law.1721

B. Protecting Officials from At-Will Removal .....................1724

III. Impartiality Regulations........................................................1728

A. Designing and Implementing Impartiality Regulations.1729

1. The Special Counsel Regulations as a Template ..........1730

2. Defining "Adjudicators" ..............................................1731

3. Implementing Impartiality Regulations .........................1732

B. The Substance of the Impartiality Regulations................1733

1. Discipline-and-Removal Provisions..............................1733

2. Merit-Based Appointment ..............................................1737

3. Additional Provisions ......................................................1739

C. Potential Concerns ............................................................1742

1. The Costs of Regulating Impartiality .............................1743

2. Shirking Congressional and Judicial Responsibility....1744

3. The Necessity of Political Will ........................................1745

Conclusion 1747

\section{INTRODUCTION}

The Supreme Court has diligently ignored answering a problem of its own making: Is the current statutory insulation that federal administrative adjudicators have from at-will removal constitutional? The answer proves elusive because it requires untangling the Court's interpretations of at least two competing constitutional provisionsthe Due Process and Take Care Clauses. ${ }^{1}$

1. Because the Supreme Court has also indicated that a federal official's status as an officer or employee may affect how much oversight the president must have over that official, the Appointments Clause may add another constitutional provision into the mix. See Free Enter. 
The problem arose in Free Enterprise Fund v. Public Co. Accounting Oversight Board ${ }^{2}$ in $2010 .^{3}$ In that decision, the Court considered whether Congress could cocoon members of the Public Company Accounting Oversight Board ("PCAOB") within two levels of protection from at-will removal. One level directly protected the PCAOB members from at-will removal by the Securities and Exchange Commission ("SEC"), while a second level protected the SEC commissioners from the president's at-will removal. ${ }^{4}$ The Court held that dual for-cause provisions impermissibly limited the president's oversight of administrative officials. ${ }^{5}$ The dissenting Justices noted that, among numerous other examples within the federal bureaucracy, the federal government's now nearly two thousand "administrative law judges" ("ALJs") 6 enjoyed dual-cause protection, and the dissenters suggested that ALJs' protection would be unconstitutional under the majority's holding. ${ }^{7}$ The majority suggested in response that ALJs' dual for-cause insulation may be constitutional because of their status as employees-not "inferior officers" of the United States-or adjudicators. ${ }^{8}$

Yet only eight years later in Lucia v. SEC, ${ }^{9}$ the Court held that the SEC's ALJs were indeed "inferior officers" because of their trialjudge-like powers. ${ }^{10}$ Despite appearing to bring ALJs' insulation within the reach of Free Enterprise Fund, the Court again punted on the constitutionality of ALJs' insulation, ${ }^{11}$ over Justice Breyer's and the government's objections. ${ }^{12}$ Lucia's holding that ALJs are officers of the United States does more than set aside a possible justification for

Fund v. Pub. Co. Accounting Oversight Bd. (PCAOB), 561 U.S. 477, 507 n.10 (2010) (noting that administrative law judges' status as "Officers of the United States" is disputed, and thus they may be able to have dual for-cause provisions to protect them from at-will removal if they are merely employees).

2. Free Enter. Fund v. Pub. Co. Accounting Oversight Bd. (PCAOB), 561 U.S. 477 (2010).

3. Id. at $483-84$.

4. See id. at 486-87 (describing express and implicit removal provisions).

5. Id. at 484-98.

6. See OfFICE OF Pers. MGMt, ALJs By AGEnCY, https://www.opm.gov/services-foragencies/administrative-law-judges/\#url=ALJs-by-Agency [https://perma.cc/3B6C-95AC] (listing 1,931 ALJs as of March 2017).

7. See Free Enter. Fund, 561 U.S. at 542-53 (Breyer, J., dissenting).

8. See id. at 507 n.10 (majority opinion).

9. Lucia v. SEC, 138 S. Ct. 2044 (2018).

10. See id. at 2053-54 (2018) (explaining why the SEC ALJs were "inferior officers" under the Court's earlier decision in Freytag v. Commissioner, 501 U.S. 868 (1991)).

11. Id. at 2050 n.1.

12. Id. at 2060-62 (Breyer, J., concurring in part and dissenting in part). 
ALJs' insulation. It also calls into question the constitutionality of at least some of the significantly more numerous, yet often forgotten, cadre of non-ALJ adjudicators that perform ALJ-like functions and have similar double insulation from at-will removal. ${ }^{13}$ These non-ALJ adjudicators include immigration judges, administrative judges, and other adjudicators with various titles.

Why has the Court been so hesitant to address agency adjudicators' dual for-cause protection from at-will removal? The answer likely lies in the tension between two constitutional provisions. ${ }^{14}$ After Free Enterprise Fund, the first provision-the Take Care Clause-limits all or certain inferior officers to only one level of "good cause" protection from removal or discipline between them and the president in the executive-branch hierarchy. ${ }^{15}$ Two or even three layers of "good cause" protection insulate ALJs: one for them, one for the independent agency that reviews their removals, and sometimes one for the head of the ALJs' employing department. ${ }^{16}$ ALJs' insulation thus appears to offend Article II.

Direct at-will removal of ALJs, however, likely undermines ALJs' objective appearance of impartiality because department heads can hold the subtle threat of discipline or removal over ALJs to encourage them to favor agency positions. ${ }^{17}$ Another constitutional provisionthe Due Process Clause-requires impartiality for agency adjudication, ${ }^{18}$ but whether impartiality entails protection from at-will removal is less clear. In short, Congress may be damned if it insulates agency adjudicators and damned if it does not.

13. See generally Kent Barnett, Some Kind of Hearing Officer, 94 WASH. L. REV. 515 (2019) [hereinafter Barnett, Some Kind of Hearing Officer] (discussing the functions of non-ALJ adjudicators and their reported numbers).

14. See generally Kent Barnett, Resolving the ALJ Quandary, 66 VAND. L. REV. 797 (2013) [hereinafter Barnett, Resolving the ALJ Quandary] (referring to the tension over insulating ALJs from at-will removal between Free Enterprise Fund and Lucia as the "ALJ quandary").

15. See Free Enter. Fund v. PCAOB, 561 U.S. 477, 496-97 (2010) (invalidating the second of two good-cause statutory protections for PCAOB members to ensure sufficient presidential oversight under the Take Care Clause).

16. See Barnett, Resolving the ALJ Quandary, supra note 14, at 807 ("Agencies may remove and generally discipline ALJs only for 'good cause established and determined by the Merit Systems Protection Board' [("MSPB")] after a formal administrative hearing. The MSPB members, like ALJs, also enjoy tenure protection because the President can remove them 'only for inefficiency, neglect of duty, or malfeasance in office." (quoting 5 U.S.C. $\$ 7521$ (a) (2018))).

17. See Free Enter. Fund, 561 U.S. at 493 ("[O]ne who holds his office only during the pleasure of another, cannot be depended upon to maintain an attitude of independence against the latter's will." (quoting Humphrey's Ex'r v. United States, 295 U.S. 602, 629 (1935))).

18. Schweiker v. McClure, 456 U.S. 188, 195 (1982). 
Scholars and regulated parties have taken note. Two prominent scholars, for instance, have recently called for doctrinal modification in light of the collision between the two provisions. ${ }^{19}$ Regulated parties have also challenged ALJs' insulation. Although early district court challenges proved unsuccessful, ${ }^{20}$ the Fifth Circuit recently considered the issue so significant that it took the extraordinary step of enjoining an adjudication before an SEC ALJ until after the court had resolved the constitutionality of the ALJ's protection from at-will removal. ${ }^{21}$

Solutions to this problem may prove difficult. On the one hand, striking down agency adjudicators' immediate statutory protection from at-will removal will only undermine their appearance of impartiality because the supervising official can now remove adjudicators at will. On the other hand, removing the second layer of "good cause" protection shielding adjudicators' heads of department or the agency that reviews adverse action against adjudicators would be a significantly disruptive remedy. Such action might undermine independent regulatory agencies altogether ${ }^{22}$ or subvert the entire civil service model that has been in place for more than four decades. ${ }^{23}$

A more functional approach to the president's removal power could account for due process concerns in the context of agency adjudication and thereby permit adjudicators' protection from at-will removal. ${ }^{24}$ But the Supreme Court has taken a formalist approach to

19. See generally, e.g., Linda D. Jellum, "You're Fired!" Why the ALJ Multi-Track Dual Removal Provisions Violate the Constitution and Possible Fixes, 26 GEO. MASON L. REV. 705 (2019) (calling for, among other things, a more wholesale overruling of the Court's removal-power jurisprudence); Richard J. Pierce, Jr., The Court Should Change the Scope of the Removal Power by Adopting a Pure Functional Approach, 26 GEO. MASON L. REV. 657 (2019).

20. See infra note 83 for a list of challenges to ALJs' insulation from at-will removal.

21. Cochran v. SEC, No. 19-10396 (5th Cir. Sept. 25, 2019) (order granting preliminary injunction); see also Peter Rasmussen, Analysis: Lack of Removal Power Could Threaten SEC ALJ Regime, BloOMBERG L. (Oct. 7, 2019, 6:48 AM), https://news.bloomberglaw.com/bloomberg-law-analysis/analysis-lack-of-removal-power-couldthreaten-sec-alj-regime [https://perma.cc/5XRL-CL59] (discussing the Fifth Circuit's injunction and its implications).

22. See Free Enter. Fund, 561 U.S. at 502 (discussing precedent concerning good-cause provisions).

23. See Gerald E. Frug, Does the Constitution Prevent the Discharge of Civil Service Employees?, 124 U. PA. L. REV. 942, 961 (1976) (noting that by the Nixon administration, "[t]he right of every civil servant to an outside appraisal of the grounds for dismissal has thus recently replaced the historic emphasis on executive discretion").

24. See generally Pierce, supra note 19 (calling for courts to adopt a functional approach when defining the scope of the removal power). 
their recent removal-power jurisprudence. ${ }^{25}$ Other solutions-such as permitting the D.C. Circuit to appoint agency adjudicators as an interbranch appointment - may prove politically infeasible. ${ }^{26}$

This Article proposes an executive-branch solution that avoids constitutional fisticuffs between competing provisions, as well as complicated legislative responses. Namely, the White House and agencies should use executive orders and regulations to mimic and improve administrative adjudicators' existing statutory protections from at-will removal. I refer to these orders and regulations collectively as "impartiality regulations."

These regulations are one example of what scholars term "internal separation of powers": internal executive-branch action that furthers other constitutional or policy objectives. ${ }^{27}$ The key benefits of internal separation of powers, like those proposed here, are that they permit the executive to fashion separation in useful ways that address specific, nuanced problems - such as the impartiality of adjudicators within the omnibus civil service - without offending the constitutional separation of powers among the branches. To be sure, an internally focused executive regulatory scheme may lack the long-term stability of a similar statutory scheme, but it is attractive as a second-best response to mitigate or moot any political impasse or judicial disruption to the existing insulation for adjudicators. In fact, impartiality regulations can go beyond at-will removal to improve the impartiality of agency adjudication, for example, by prohibiting ex parte contacts and limiting how agencies go about awarding pay bonuses to adjudicators. In other words, whether or not the Supreme Court places ALJs outside of Free Enterprise's tiered-removal prohibition, impartiality regulations are a useful device for legitimizing and ameliorating agency adjudication.

Impartiality regulations do not undermine the president's obligation to "take Care that the Laws be faithfully executed." 28 The Take Care Clause requires the executive to ensure agency adjudicators are impartial under the Due Process Clause as much as it requires the

25. See Kent Barnett, Standing for (and up to) Separation of Powers, 91 IND. L.J. 665, 67576, 710-14 (2016) [hereinafter Barnett, Standing For] (discussing the Roberts Court's consistently formalist approach to separation of powers, including the president's removal power under Article II, and calling for a more functional approach).

26. See Barnett, Resolving the ALJ Quandary, supra note 14, at 832-35 (proposing that the D.C. Circuit appoint and remove ALJs to protect ALJ impartiality without implicating Free Enterprise Fund's dual for-cause prohibition).

27. See infra Part II.

28. U.S. CONST. art. II, $\S 3$. 
executive to enforce regulatory statutes faithfully in a manner that does not violate other constitutional rights. Control and insulation are both useful, if not necessary, tools for executive enforcement. And even in the absence of constitutional imperatives, impartiality and tiered insulation for adjudicators inure to the benefit of not only regulated parties but also agencies themselves by giving executive action more legitimacy. The executive's provision of civil service protections during the nineteenth and twentieth centuries strongly suggests that the executive recognizes the long-term benefits of insulating executive officials.

This Article proceeds in three parts. Part I considers the agencyadjudicator dilemma (i.e., the dilemma of insulating adjudicators from at-will removal in a way that protects their impartiality without offending the president's supervisory power under Article II), how it developed, and some of the potential, but lacking, solutions. Part II reviews the theoretical grounding of internal separation of powers and its current uses. It then discusses the executive branch's long-standing use of executive orders to protect executive officials from at-will removal. Part III details how the executive branch should go about resolving the agency-adjudicator dilemma via impartiality regulations. Specifically, this Part proposes creating impartiality regulations to address the removal, hiring, and other indicia of impartiality for agency adjudicators. Finally, Part III considers potential obstacles to the promulgation of impartiality regulations, including hostility or disinterest from current or future administrations. Ultimately, impartiality regulations indicate that the executive is not simply at the mercy of Congress or judicial doctrine. The executive has, if you will, its own agency in improving its supervision and insulation of agency adjudicators.

\section{THE AGENCY-ADJUDICATOR DILEMMA}

The dilemma over administrative-adjudicator insulation boils down to how to balance political and managerial control or supervision with impartiality. For instance, the Trump administration has sought to impose significant case-processing goals on immigration judges to ensure prompt adjudication. The immigration judges, for their part, contend that the goals are unrealistic and improperly encourage them to limit hearings and deny immigrants' claims-consistent with the 
administration's expressed preference. ${ }^{29}$ This Part considers how dilemmas like this arise under the Take Care and Due Process Clauses by considering each clause's development, how the Court has sought to avoid resolving the dilemma, and previously proposed solutions.

This agency-adjudicator dilemma has come to encompass two similar, but distinct, groups of federal adjudicators. The first are ALJs, who number around two thousand. ${ }^{30}$ ALJs were created by the Administrative Procedure Act of 1946 ("APA") to preside over "on the record" agency hearings. ${ }^{31}$ As discussed in more detail in later parts, the APA requires ALJs to be "impartial" and limits their duties, ex parte contacts, and agency supervision. ${ }^{32}$ Until recently, agencies selected ALJs under a merit-based process led by the Office of Personnel Management ("OPM") that limited agencies to hiring one of the three top-scoring candidates. ${ }^{33} \mathrm{~A}$ recent executive order, however, has removed ALJs from the "competitive service" and permitted direct agency hiring. ${ }^{34}$ Agencies can take adverse actions, as defined by statute, against ALJs "only for good cause established and determined by the Merit Systems Protection Board [("MSPB")] on the record after opportunity for hearing." ${ }^{35}$ ALJs cannot receive performance reviews or bonuses. ${ }^{36}$

Lacking any uniform title, the second group of adjudicators is often collectively, if inelegantly, styled as simply "non-ALJ adjudicators" or "non-ALJs" for short. Although difficult to define, ${ }^{37}$

29. See Barnett, Some Kind of Hearing Officer, supra note 13, at 517-18 (discussing the current debate over the supervision of immigration judges).

30. See OfFICE Of Pers. MGMT., supra note 6 (listing 1,931 ALJs).

31. See 5 U.S.C. § 556(a)-(b) (2018) (discussing on-the-record hearings).

32. See infra Part III.

33. See Kent Barnett, Against Administrative Judges, 49 U.C. DAVIS L. REV. 1643, 1654-55 (2016) [hereinafter Barnett, Against Administrative Judges] (describing the long-standing ALJhiring process).

34. Exec. Order No. 13,843, 83 Fed. Reg. 32,755 (July 10, 2018). For additional thoughts on the executive order and changes to ALJ hiring, see Kent Barnett, Raiding the OPM Den: The New Method of ALJ Hiring, 36 YAle J. ON Reg.: Notice \& CoMment (July 11, 2018), $\mathrm{http} / / /$ yalejreg.com/nc/raiding-the-opm-den-the-new-method-of-alj-hiring-by-kent-barnett [https://perma.cc/L6Q6-PV73]. Senators Maria Cantwell and Susan Collins have introduced a bill to largely restore and codify the traditional OPM-led ALJ-hiring process. ALJ Competitive Service Restoration Act, S. 2348, 116th Cong. (2019).

35. 5 U.S.C. $\$ 7521$ (a)-(b) (2018).

36. See Barnett, Against Administrative Judges, supra note 33, at 1655-56 (discussing limitations on supervising or rewarding ALJs).

37. See infra Part III.A.2. 
they number more than ten thousand under broad definitions. ${ }^{38}$ One empirical study has determined that of 432 federal adjudicatory schemes, 103 are presided over by ALJs, while 230 are presided over by non-ALJ adjudicators. ${ }^{39}$ Non-ALJ adjudicators go by many titles, including hearing officer, administrative judge, or immigration judge. ${ }^{40}$ They may or may not be created by statute, ${ }^{41}$ and no uniform provisions govern their impartiality and job performance. They are hired from within and from outside the agency. They are usually subject to performance reviews and eligible for bonuses. They can be removed or disciplined only for cause with review by the MSPB. Unlike with ALJs, the MSPB does not itself initially determine whether cause exists to discipline or remove non-ALJ adjudicators. ${ }^{42}$

\section{A. Due Process}

Due process requires that all adjudicators-whether judicial or administrative and whether in federal or state proceedings-be impartial. ${ }^{43}$ Because partiality can be extremely difficult to prove, partiality inquiries nearly always concern the objective risk, probability, potential, or appearance of partiality. ${ }^{44}$ Creating an appearance of impartiality serves as a prophylaxis for limiting unconscious partiality and thus for achieving actual impartiality. ${ }^{45}$

38. Kent Barnett \& Russell Wheeler, Non-ALJ Adjudicators in Federal Agencies: Status, Selection, Oversight, and Removal, 53 GA. L. REV. 1, 33-34 fig.1 (2019).

39. Schemes, ADJUDICATION RESEARCH, https://acus.law.stanford.edu/schemes [https://perma.cc/PD4F-S2C9] (sorting by Type A for schemes presided over by ALJs and Type $\mathrm{B}$ for those presided over by non-ALJs).

40. See Barnett, Against Administrative Judges, supra note 33, at 1659-60; Barnett \& Wheeler, supra note 38, at 37-38 fig.3 (listing the numerous reported titles for non-ALJ adjudicators).

41. See Barnett, Against Administrative Judges, supra note 33, at 1659.

42. See generally Barnett \& Wheeler, supra note 38, for an in-depth discussion over their indicia of impartiality. Compare 5 C.F.R. $\$ 1201.2$ (noting MSPB's original jurisdiction extends to actions against ALJs), id. $\S 1201.137$ (noting that agencies must file complaints with the MSPB to take a proposed adverse action against ALJs), and id. $\S 1201.140$ (2019) (noting that MSPB permits adverse action against an ALJ only if the MSPB finds "good cause"), with id. $\S 1201.21$ (noting MSPB hears appeals from employees against whom agencies have taken adverse action).

43. Schweiker v. McClure, 456 U.S. 188, 195 (1982).

44. See Barnett, Against Administrative Judges, supra note 33, at 1671-73; see also generally Williams v. Pennsylvania, 136 S. Ct. 1899, 1909 (2016) (referring to the "appearance of neutrality"); Caperton v. A.T. Massey Coal Co., 556 U.S. 868, 884, 886, 887 (2009) (describing the appropriate standard as one of probability, risk, and potential).

45. See Dmitry Bam, Making Appearances Matter: Recusal and the Appearance of Bias, 2011 BYU L. REV. 943, 966-67 (discussing the difficulty in ferreting out actual bias). 
Which circumstances create the risk or appearance of partiality are far from clear, although the Supreme Court has recently identified new factors to consider. The Supreme Court has indicated that the following can serve as indicia of partiality: substantial contributions for judicial elections, ${ }^{46}$ remuneration or other "direct, personal, substantial, pecuniary interest" tied to judicial decisions; ${ }^{47}$ a current judge's prior involvement in a case as counsel for a party; ${ }^{48}$ and certain relationships between judges and parties or their counsel. ${ }^{49}$ Perhaps most relevant for administrative adjudicators, the Court has reemphasized in the Article II context that "one who holds his office only during the pleasure of another, cannot be depended upon to maintain an attitude of independence against the latter's will." ${ }^{50}$ Nevertheless, the Court has never ruled directly on agencies' ability to remove, discipline, or reward their adjudicators or indicated whether any particular limitations on these actions exist.

Yet even from the Supreme Court's rough sketch of due process's requirements, the concerns over agencies or the president removing administrative adjudicators at will is obvious. If agency superiors can remove adjudicators at will-or, as is the case with certain non-ALJ adjudicators, can award them bonuses ${ }^{51}$-then the agency superiors can exert pressure on the adjudicators to rule in agency-friendly ways. This concern is most pronounced in enforcement proceedings when, as is often the case, the agency is a party. ${ }^{52}$ But even when the agency is

46. Caperton, 556 U.S. at 884.

47. Tumey v. Ohio, 273 U.S. 510, 523 (1927).

48. Williams, $136 \mathrm{~S}$. Ct. at 1905.

49. Schweiker v. McClure, 456 U.S. 188, 197 n.11 (1982).

50. Free Enter. Fund v. PCAOB, 561 U.S. 477, 493 (2010) (quoting Humphrey's Ex'r v. United States, 295 U.S. 602, 629 (1935)). In fact, when interpreting a statute that permitted the adjudication of war claims before a commission, the Court inferred that Congress intended for the commissioners to have protection from at-will removal:

If, as one must take for granted, the War Claims Act precluded the President from influencing the Commission in passing on a particular claim, a fortiori must it be inferred that Congress did not wish to have hang over the Commission the Damocles' sword of removal by the President for no reason other than that he preferred to have on that Commission men of his own choosing.

Wiener v. United States, 357 U.S. 349, 356 (1958).

51. See generally Barnett \& Wheeler, supra note 38, at 73-83 (discussing reported non-ALJ adjudicators who are eligible and receive bonuses from their agencies).

52. See Administrative Procedure Act Legislative History, S. Doc. No. 248 (1946), reprinted in COMM. ON THE JUDICIARY, 79TH CONG., LEGISLATIVE HISTORY OF THE AdMINISTRATIVE PROCEDURE ACT 262 (1946) [hereinafter APA LEG. HistORY] (noting that the need for adjudicator independence was at its apex when agencies were a party to "accusatory" proceedings). 
not a party, the agency may have preferences that it subtly seeks to impose on adjudicators. Indeed, even those who adhere to strong executive-power theories of presidential authority often recognize the problem with permitting the president or agency superiors to instruct agency adjudicators on how to rule..$^{53}$

Yet due process impartiality principles must have some kind of exception or slack for administrative adjudication or else they would cease to exist in their current form. Under general administrative law principles, the head of an agency can reverse an agency adjudicator's decision in toto and can even hear adjudications in the first instance. ${ }^{54}$ Because numerous heads of agencies-including all Cabinet-level heads-can be removed by the president at will and hear or review adjudications, any absolute impartiality rule that required insulation from at-will removal would entirely destabilize agency adjudication in existing nonindependent executive agencies. In effect, adjudications for such agencies would violate due process unless Congress acted to provide protection from the president's at-will removal. The fact that agency adjudication by agency officials subject to at-will removal goes back to the Founding severely undercuts, or at least complicates, a broad application of due process to all agency officials. ${ }^{55}$

The need for such a significant impartiality exception only arose after the Court expanded the reach of due process. ${ }^{56}$ Traditionally, due process applied only to the deprivation of one's "right" to life, liberty,

53. See Myers v. United States, 272 U.S. 52, 135 (1926); see also Cynthia R. Farina, Undoing the New Deal Through the New Presidentialism, 22 HARV. J.L. \& PUB. POL'Y 227, 233-34 (1998) ("[E]ven the most ardent presidentialists have been careful to insist that the Chief Executive could not intervene to direct the outcome of particular cases.").

54. See 5 U.S.C. $§ 556$ (b) (2018) (permitting "the agency," "one or more members of the body which comprises the agency," or an ALJ to take evidence); id. $\S 557$ (b) (confirming that "the agency has all the powers which it would have in making the initial decision" when reviewing decisions); Christopher J. Walker \& Melissa F. Wasserman, The New World of Agency Adjudication, 107 CAL. L. REV. 141, 143-44 (2019) (noting that the traditional model of federal agency adjudication leaves decision-making authority with the agency head).

55. Cf. James D. Ridgway, Equitable Power in the Time of Budget Austerity: The Problem of Judicial Remedies for Unconstitutional Delays in Claims Processing by Federal Agencies, 64 ADMIN. L. REV. 57, 73-74 (2012) (discussing the adjudicatory system concerning benefits for Revolutionary War veterans and their widows, and the Supreme Court's constitutional and pragmatic concerns with judicial involvement in benefits adjudication run by the Secretary of War).

56. Cf. Jennifer L. Mascott, Constitutionally Conforming Agency Adjudication, 2 LOY. J. REG. COMP. 22, 42-51 (2017) (arguing for a more limited sphere of appropriate agency adjudication and noting changes in due process and Article III doctrine). 
or property - not the awarding or revocation of benefits or privileges. ${ }^{57}$ Until the early twentieth century, nearly all federal administrative action concerned benefits or privileges.$^{58}$ Relevant deprivations would occur only with judicial process, as due process included one's right to Article III courts. ${ }^{59}$ But due process's reach expanded significantly in the twentieth century. Regulatory enforcement grew $^{60}$ as judicial review shrank. ${ }^{61}$ And perhaps most importantly, the Court reconceived protected "property" interests to include "legitimate claim[s] of entitlement" to what would have been traditionally characterized as benefits and privileges. ${ }^{62}$ Without these developments, due processand especially its impartiality prong-may have reached very little administrative adjudication.

Nonetheless, before due process's expanded reach to government benefits, Congress and agencies recognized the relationship between financial incentives and the impartiality of agency and judicial adjudication. When an agency or other federal officials received what Professor Nicholas Parrillo refers to as "facilitative payments"payments from those needing a government benefit or service ${ }^{63}-$ they skirted required factual findings or other legislative limitations when adjudicating matters related to citizenship, veterans' benefits, and federal land. By doing so, they encouraged lucrative payments from future applicants. Congress, in response, moved these decisions to salaried officials and prohibited those officials from accepting facilitative payments. Notably, Congress recognized that an adjudicator's incentive to continue or increase his income could influence decision-making, even if Congress had not tied the

57. Hiroshi Motomura, The Curious Evolution of Immigration Law: Procedural Surrogates for Substantive Constitutional Rights, 92 COLUM. L. REV. 1625, 1650-51 (1992).

58. See Gordon G. Young, Public Rights and the Federal Judicial Power: From Murray's Lessee Through Crowell to Schor, 35 BUFF. L. REV. 765, 798, 819 (1986) (discussing the expansion of the concept of "public rights" in the nineteenth and early twentieth centuries).

59. See Nathan S. Chapman \& Michael W. McConnell, Due Process as Separation of Powers, 121 YALE L.J. 1672, 1720, 1802-03 (2012) (stating that "Article III limited the range of cases in which Congress could violate due process by exercising quasi-judicial power" while recognizing the open question of "whether the Due Process Clause . . . still requires that some traditional core of cases be decided in court, rather than in executive-branch agencies").

60. See Young, supra note 58, at 819-23 (discussing a shift to increased administrative enforcement).

61. See, e.g., Crowell v. Benson, 285 U.S. 22, 46-50 (1932) (discussing the permissibility of deferential review to agency fact finding even in matters between private parties).

62. Bd. of Regents of State Colls. v. Roth, 408 U.S. 564, 577 (1972).

63. Nicholas R. PARrillo, Against the Profit Motive: The SAlary Revolution IN AMERICAN GOVERNMENT, 1780-1940, at 2 (2013). 
adjudicator's pay to how he ruled in any particular case. ${ }^{64}$ The key difference between concerns then and now is not the nature of the incentive but whom the financial incentives benefit. Then, the individual who approached the agency paid the fee and stood to benefit. Now, the agency-often a party to agency adjudication and empowered to review, pay bonuses to, and take adverse action against the adjudicator-stands to influence the adjudicator.

Where does this discussion of impartiality leave us? Due process's impartiality requirements apply to agency adjudication; the Court recognizes the relationship between impartiality and at-will removal and financial incentives; and due process most likely softens or mutes the binary quality of impartiality's reach to some agency adjudicatorsnamely, the heads of agencies. From this, one might conclude that Congress has significant authority to regulate presidential supervision of agency adjudicators, even if the Due Process Clause does not mandate any particular resolution of the tensions within the Supreme Court's due process jurisprudence.

\section{B. The Take Care Clause}

The Vesting and Take Care Clauses of Article II complicate matters, however. Many leading scholars and jurists think Congress, in the well-known "Decision of 1789," decided that the Constitution permitted the president to remove executive officers alone, even without impeachment proceedings. ${ }^{65}$ James Madison argued that removal by the president alone encourages executive officials to be more faithful and prompt in discharging their duties ${ }^{66}$ Similar concerns continue today, as governmental supervisors often complain of their inability to discipline or remove "nonproductive or insubordinate employees." ${ }^{67}$

64. See id. at 19-23, 125-79 (discussing key examples of the problems with facilitative payments and Congress's response).

65. See generally Saikrishna Prakash, New Light on the Decision of 1789, 91 CORNELL L. REV. 1021, 1022-26 (2006) (describing the nature of the debate and its contested meaning to scholars and jurists). Others have argued that its meaning is ambiguous. See id. at 1023-25 (discussing the views of scholars Edward Corwin and David Currie, and Justice Louis Brandeis in dissent in Myers v. United States, 272 U.S. 52 (1926)).

66. 1 AnNALs OF CONG. 495, 499 (1789) (Joseph Gales ed., 1834) (statement of James Madison).

67. Frug, supra note 23, at 945 (quoting JOHN W. MACY, PUBliC SERVICE: THE HUMAN SIDE OF GOVERNMENT 20 (1971)). Moreover, as Professor Frug suggests, a good-cause limitation can prove problematic in practice, even if not in theory. $I d$. at 946 . One of the practical problems is defining "good cause" in its various formulations. One common form of good-cause removal 
Over time, the Court recognized that Article II permits certain congressionally imposed limitations on removal. In brief, Congress can limit at-will removal of inferior officers appointed by department heads ${ }^{68}$ or by a court of law, ${ }^{69}$ and Senate-confirmed principal officers. ${ }^{70}$ The Court has even gone so far as to interpret a statute, despite its silence on the matter, as requiring good-cause removal for certain principal officers with only adjudicatory duties. ${ }^{71}$ Moreover, the Civil Service Act of 1978 prohibits at-will removal for the federal civil service, ${ }^{72}$ and I am unaware of any challenge under Article II to that statutory scheme. These decisions suggest that statutory limitations on agency adjudicators' at-will removal-whether or not compelled by due process-are permissible under Article II, especially for the numerous inferior officers or employees.

Then along came Free Enterprise Fund. There, the Court considered whether the good-cause removal protections for the PCAOB members violated Article II. Under the Board's implementing statute, the SEC could appoint members for staggered five-year terms ${ }^{73}$ and could remove them for only extremely limited causes. ${ }^{74}$ Based on the parties' agreement, the Court assumed that,

permits removal for only "inefficiency, neglect of duty, or malfeasance in office." E.g., 12 U.S.C. $\S 5491$ (c)(3) (2012). In a recent case, judges on the en banc D.C. Circuit jousted over whether the president could remove officers with such good-cause protection for mere policy disagreements. Compare PHH Corp. v. CFPB, 881 F.3d 75, 122-24 (D.C. Cir. 2018) (Wilkins, J., concurring) ("Such a capacious construction would essentially remove the concept of 'independence' from 'independent agencies."'), with id. at 134-35, 136-37 (Griffin, J., concurring) ("[T]hese removal grounds ... provide only a minimal restriction on the President's removal power, even permitting him to remove the Director for ineffective policy choices."). Notably, the Supreme Court had earlier stated that its precedents would not suggest that a president could remove an officer over mere policy disagreements. See Free Enter. Fund v. PCAOB, 561 U.S. 477, 502 (2010) ("[T]he Government does not contend that simple disagreement with the Board's policies or priorities could constitute 'good cause' for its removal. . . Nor do our precedents suggest as much.").

68. See United States v. Perkins, 116 U.S. 483, 485 (1886) (upholding the Secretary of the Navy's ability to remove a cadet engineer only through court martial).

69. See Morrison v. Olson, 487 U.S. 654, 691-92 (1988) (upholding good-cause removal for a special counsel appointed by the Special Division of the D.C. Circuit).

70. See Humphrey's Ex'r v. United States, 295 U.S. 602, 631-32 (1935) (upholding limitations on at-will removal of a Federal Trade commissioner).

71. See Wiener v. United States, 357 U.S. 349, 353-54 (1958) (interpreting a statute to permit only for-cause removal of War Claims commissioners).

72. See 5 U.S.C. $\$ 7513$ (a) (2018). The statutory scheme also provides for administrative appeal to the MSPB and judicial review of the MSPB's order. See id. $\S \S 7701(a), 7703(a)$.

73. Free Enter. Fund v. PCAOB, 561 U.S. 477, 484 (2010).

74. Id. at 486. The SEC could remove the PCAOB members after a formal hearing for the willful violation of certain laws, the willful abuse of authority, and unreasonable failure to enforce certain accounting laws. 15 U.S.C. $§ 7217(d)(3)(2012)$. 
despite congressional silence, the president could remove the SEC commissioners only for "inefficiency, neglect of duty, or malfeasance in office." 75 The Court held that Congress's cocooning of the PCAOB members within two "tiers" of protection from the president violated the Vesting and Take Care Clauses of Article II. ${ }^{76}$ Although the Court had earlier upheld protection from at-will removal for both principal officers like the SEC commissioners and inferior officers appointed by a department head like the PCAOB members, the Court held that the two otherwise permissible tiers were unconstitutional when combined. The problem was that the president could not hold the SEC accountable for its oversight of the PCAOB as he could for all of its other actions. Because neither the president nor anyone under his direct control had full authority over the PCAOB, Congress had dispersed responsibility for government action throughout the administrative state and insulated the president from political accountability for executive actions. ${ }^{77}$

The dissenting Justices identified many officials and statutory schemes with tiered protections from at-will removal that the majority's decision threatened. They included umpteen Senior Executive Service members in the civil service (including numerous senior leaders in scientific agencies), military personnel, much of the federal civil service, ${ }^{78}$ and-most importantly for my purposesadministrative law judges. ${ }^{79}$ Recall that agencies can remove or otherwise take adverse action against ALJs "only for good cause established and determined by the [MSPB] on the record after opportunity for hearing." ${ }^{80}$ The MSPB's members, who are appointed to seven-year terms following Senate confirmation, are also protected from at-will removal. ${ }^{81} \mathrm{~A}$ small number of non-ALJ adjudicators have the same statutory protection as ALJs from at-will removal. ${ }^{82}$

75. Free Enter. Fund, 561 U.S. at 487 (quoting Humphrey's Ex'r, 295 U.S. at 620).

76. Id. at 484 .

77. See id. at 496-97.

78. See id. at 538-42, 543-44 (Breyer, J., dissenting).

79. See id. at 542-43.

80. 5 U.S.C. $\$ 7521(a)(2018)$.

81. Id. $\S 1202(\mathrm{a}),(\mathrm{d})$.

82. See 41 U.S.C. $§ 7105(b)(3)$ (2012) ("Members of the Civilian Board are subject to removal in the same manner as administrative law judges, as provided in section 7521 of title 5."). There are currently fourteen judges on the U.S. Civilian Board of Contract Appeals. See Judges, U.S. CIVILIAN BD. OF CONTRACT APPEALS, https://www.cbca.gov/board/judges.html [https://perma.cc/WM4U-K5JU] (this number of judges is current as of December 2019). 
Numerous litigants have taken notice and asserted Article II removalbased challenges against ALJs. ${ }^{83}$

Nearly all other non-ALJ agency adjudicators are in a similar, although not identical, state as ALJs. Civil service protections shelter non-ALJ adjudicators from at-will removal. ${ }^{84}$ But their protection from removal is not as robust as the protection for ALJs. ${ }^{85}$ Although the MSPB reviews adverse actions against civil servants by their employing agencies ${ }^{86}$ and requires a rational basis or substantial evidence for the action ${ }^{87}$ the MSPB does not determine whether cause for the adverse action exists in the first instance.$^{88}$ If the MSPB's more limited review somehow does not bring the civil service-including non-ALJ adjudicators - within Free Enterprise Fund's prohibition, many nonALJ adjudicators work for independent agencies whose head the

83. See Bebo v. SEC, 799 F.3d 765, 768 (7th Cir. 2015); Cochran v. SEC, No. 4:19-CV-066A, 2019 WL 1359252, at *2 (N.D. Tex. Mar. 25, 2019); Morris \& Dickson Co. v. Whitaker, 360 F. Supp. 3d 434, 437 (W.D. La. 2018); Bennett v. SEC, 151 F. Supp. 3d 632, 634 (D. Md. 2015), aff'd, 844 F.3d 174 (4th Cir. 2016); Tilton v. SEC, No. 15-CV-2472, 2015 WL 4006165, at *2 (S.D.N.Y. June 30, 2015), aff'd, 824 F.3d 276 (2d Cir. 2016); Hill v. SEC, 114 F. Supp. 3d 1297, 1304-05 (N.D. Ga. 2015), vacated and remanded by 825 F.3d 1236 (11th Cir. 2016); Duka v. SEC, 103 F. Supp. 3d 382, 388 (S.D.N.Y. 2015), abrogated by Tilton v. SEC, 824 F.3d 276 (2d Cir. 2016).

84. 5 U.S.C. § 7513(a) (2018) ("Under regulations prescribed by [OPM], an agency may take an action covered by this subchapter against an employee only for such cause as will promote the efficiency of the service.").

85. Arthrex, Inc. v. Smith \& Nephew, Inc., 941 F.3d 1320, 1333 n. 4 (Fed. Cir. 2019) (“Section 7513 [the provisions of protection for removal for the civil service] contains a lower threshold to support removal than does $\$ 7521$ [the provision that protects ALJs from removal]."). The Federal Circuit, however, declined to consider the "circumstances which could justify a removal for such cause as would promote the efficiency of service." Id. at 1333 n.5.

86. 5 U.S.C. $\$ 7513(\mathrm{~d})$.

87. See Phillips v. Bergland, 586 F.2d 1007, 1012 (4th Cir. 1978) (noting that courts applied either the rational-basis or substantial-evidence standards).

88. Compare 5 U.S.C. $\S 7521$ (a) (referring to the MSPB's ability to determine and establish whether good cause exists), with id. § 7513(a), (d) (permitting an agency itself to take action and later appeal). The legislative history expands further on the merits of securing greater independence for ALJs in this context:

Recognizing that the entire tradition of the Civil Service Commission is directed toward security of tenure, it seems wise to put that tradition to use in the present case. However, additional powers are conferred upon the Commission. It must afford any examiner an opportunity for a hearing before acceding to an agency request for removal, and even then its action would be subject to judicial review.

S. REP. No. 752 (1946), reprinted in APA LEG. HISTORY, supra note 52, at 29. Accord H. REP. NO. 1980 (1946), reprinted in APA LEG. HISTORY, supra note 52, at 280. During the House proceedings on the APA, Representative Francis Walter noted that the ALJs' protections from removal were intended to be "full and complete," as compared to that for the civil service. 79 CONG. REC. (1946), reprinted in APA LEG. HISTORY, supra note 52, at 371. 
president can remove only for cause and thus enjoy two tiers of protection from at-will removal nonetheless. ${ }^{89}$

\section{Avoiding and Resolving the Agency-Adjudicator Dilemma}

Neither the majority nor the dissent in Free Enterprise Fund directly identified the tension between the Take Care and Due Process Clauses when discussing ALJs. But both sides appeared to recognize either the constitutional or pragmatic concerns of extending Free Enterprise Fund too far. Responding to the dissenting Justices' fears, the majority briefly proposed in a footnote two ways of distinguishing ALJs-and perhaps the entire civil service-from Free Enterprise Fund's two-tier prohibition. First, the Court suggested that ALJs were merely "employees," not "inferior officers" like the PCAOB members. Second, the Court suggested that ALJs had adjudicatory functions, while PCAOB members did not. ${ }^{90}$ But as the dissent retorted, even if these suggestions could limit Free Enterprise Fund's holding, neither is compelling. ${ }^{91}$ If these or some other exceptions do not apply to adjudicators, the most likely remedy for a two-tier prohibitionsevering one of the two tiers - either exacerbates impartiality concerns or creates more considerable problems.

1. Constitutional Status. The majority first suggested that its holding might not reach ALJs because they might be only employees, not inferior officers. ${ }^{92}$ That suggestion was short-lived. The Court confirmed only a few years later in Lucia v. SEC that the SEC's ALJs were indeed inferior officers based on two factors that the Court

89. Based on my earlier co-authored empirical project on federal non-ALJ adjudicators, the following independent agencies' non-ALJ adjudicators appear to implicate Free Enterprise Fund's tiered-protection prohibition (if the non-ALJs qualify as "officers of the United States"): the Commodity Futures Trading Commission, Equal Employment Opportunity Commission, Federal Maritime Commission, Federal Labor Relations Authority, MSPB, National Labor Relations Board, and Nuclear Regulatory Commission. See Barnett \& Wheeler, supra note 38, at 123-27 app. C.

90. Free Enter. Fund v. PCAOB , 561 U.S. 477, 507 n.10 (2010).

91. Id. at 536 (discussing the majority's proposed adjudication-based exception); see id. at 542 (Breyer, J., dissenting) (discussing certain Justices' earlier characterizations of ALJs as officers).

92. Id. at 507 n.10 (majority opinion). The Court has distinguished "Officers of the United States," to whom the Appointments Clause applies, and employees, to whom it does not. The former "exercis[e] significant authority pursuant to the laws of the United States," Buckley $v$. Valeo, 424 U.S. 1, 126 (1976) (per curiam), while the latter are "lesser functionaries subordinate to officers of the United States," id. at 126 n.162. 
applied in one of its earlier decisions, Freytag v. Commissioner ${ }^{93}$ First, the ALJs held "a continuing office established by law." 94 Second, they wielded trial-judge-like powers, including the ability to take testimony, receive and rule on the admissibility of evidence, preside over trials, enforce compliance with discovery orders, and punish "contemptuous conduct" at the hearing. ${ }^{95}$ The Court clarified that inferior-officer status did not depend upon the SEC's ALJs having the authority to issue final orders. ${ }^{96}$ Although Lucia did not go so far as to characterize all agencies' ALJs as inferior officers, all ALJs hold continuous positions established by law and carry out similar trial-like functions. ${ }^{97}$ Moreover, the Lucia Court was not receptive to making fine-grain distinctions between the SEC's ALJs and the tax-court judges at issue in Freytag. ${ }^{98}$ Accordingly, the majority's first proposed distinction between PCAOB members and ALJs has very likely disappeared.

The Lucia holding probably reaches some non-ALJ adjudicators as well. The diversity of non-ALJ adjudicators' duties and legal geneses renders it difficult to determine how many may be inferior officers. Yet, at least some non-ALJ adjudicators' statuses are in play. Agencies have reported more than ten thousand non-ALJ adjudicators who can preside over adversarial hearings. ${ }^{99}$ While overseeing such hearings, non-ALJ adjudicators likely wield many powers exercised by trial judges or ALJs - satisfying Freytag's second prong. Indeed, Freytag itself held that certain tax-court judges-Article II non-ALJs, mind

93. Freytag v. Comm'r, 501 U.S. 868 (1991).

94. Lucia v. SEC, 138 S. Ct. 2044, 2053 (2018). The Court noted that the SEC's ALJs have a career appointment with their "duties, salary, and means of appointment" provided by statute (or implementing regulations). See id. (quoting Freytag, 501 U.S. at 878).

95. Id. at $2053-54$.

96. See id. at 2053 n.4 (rejecting the view that "final decisionmaking authority is a sine qua non of officer status").

97. Perhaps the Court would distinguish the ALJs who work for the Social Security Administration ("SSA") from the SEC ALJs because they hold inquisitorial, as opposed to adversarial, hearings. But the Lucia factors would appear to apply equally to SSA ALJs: the SSA ALJs perform the functions that the Lucia Court identified, and-at any rate-they sometimes hold adversarial hearings. See 20 C.F.R. § 404.1765(a) (2019).

98. See Lucia, $138 \mathrm{~S}$. Ct. at 2054-55 (dismissing distinctions concerning adjudicators' compliance powers and agency superiors' deference to their decisions).

99. Barnett \& Wheeler, supra note 38 , at 8 . In the study, we asked agencies to report whether they had "Non-ALJ Hearings," which in brief were those in which "[o]ne of the parties to the adjudication can-by statute, regulation, or other law-obtain an oral hearing over which an agency official presides to present evidence, even if most matters are handled through written submissions without an oral hearing." Id. at 25 . For the full definition and exceptions, see $i d$. 
you-were inferior officers. ${ }^{100}$ Moreover, in Lucia's aftermath, the solicitor general counseled federal agencies to treat their non-ALJ adjudicators as inferior officers. ${ }^{101}$ The government has also agreed in recent litigation that administrative judges for the Department of Housing and Urban Development were inferior officers. ${ }^{102}$ Relatedly, the Federal Circuit recently held that the more than two hundred administrative patent judges ${ }^{103}$ were principal-not merely inferiorofficers based, in part, on their civil service protection from at-will removal. ${ }^{104}$

Whether non-ALJ adjudicators hold continuing positions established by law is a more challenging question. Some are hired on an ad hoc or part-time basis, ${ }^{105}$ although it appears that most have continuing positions. ${ }^{106}$ However, some of their positions may not be specified by statute, as ALJs' are. For instance, immigration judges have a direct statutory genesis, ${ }^{107}$ but Equal Employment Opportunity Commission administrative judges do not. ${ }^{108}$ Nonetheless, the exact contours of an office "established by [1]aw" are not well-defined. Congress may not need to refer to a position as an "office" or even specifically identify the office. Instead, the Office of Legal Counsel has focused more on the nature of the duties performed and the continuous nature of the position, perhaps reading the "established by [1]aw" predicate out of Article II altogether. ${ }^{109}$ In short, Lucia's holding may sweep up numerous non-ALJ adjudicators, but its reach is not easy to determine.

100. See Lucia, 138 S. Ct. at 2047 (citing Freytag v. Comm'r, 501 U.S. 868 (1991) as the decision that "decides this case").

101. See Memorandum from the Solicitor General, U.S. Dep't of Justice, to Agency Gen. Counsels, Guidance on Administrative Law Judges After Lucia v. SEC (S. Ct.) 3 (July 2018) [hereinafter SG Mem.].

102. See Associated Mortg. Bankers, Inc. v. Carson, No. CV 17-0075, 2019 WL 108882, at *5, *7 (D.D.C. Jan. 4, 2019).

103. Arthrex, Inc. v. Smith \& Nephew, Inc., 941 F.3d 1320, 1329 (Fed. Cir. 2019).

104. Id. at $1327-29$.

105. See Barnett \& Wheeler, supra note 38, at 35 (noting that of the reported non-ALJs, "[o]nly 39 of the 10,831 non-ALJs ... are part-time agency employees"). As an example, the FDIC reported that it hired hearing officers on an ad hoc basis. See id. at 34 fig.1.

106. See id. at 39-48.

107. See Jennifer L. Cotton, If Established by Law, Then an Administrative Judge Is an Officer, 53 GA. L. REV. 309, 333 (2018) (citing 8 U.S.C. § 1229a(a)(1) (2012)).

108. See id.

109. See Officers of the U.S. Within the Meaning of the Appointments Clause, 31 Op. O.L.C. 117-19 (2007). 
Yet, a first-order question remains: Even if certain non-ALJs are not "Officers of the United States," why should it matter for purposes of Free Enterprise Fund's two-tier prohibition whether the subordinate is an officer or an employee? Perhaps the idea is that the president needs to be able to supervise all executive officials who "exercis[e] significant authority pursuant to the laws of the United States"110 because of their policymaking authority. But should the president not have just as much authority over employees who execute ministerial functions, especially if the employee is bad at his job? Those functions - such as the ministerial duty of delivering a commission in Marbury v. Madison" ${ }^{111}$ - are equally necessary for "the Laws [to] be faithfully executed" under the Take Care Clause. ${ }^{112}$ Thus, although this distinction could save much of the civil service's insulation, it lacks any obvious normative basis.

2. Adjudication Function. Because constitutional status no longer distinguishes ALJs from the PCAOB members in Free Enterprise Fund, the Court could instead rely upon its second proposed ground: all adjudicators, or at least those who provide recommended decisions, are different in kind from the policymaking PCAOB members. ${ }^{113}$ This distinction between policymaking and adjudication is "fairly intuitive" because adjudicators are often understood to maintain the rule of law, ${ }^{114}$ not create or enforce it. It also has historical support. For example, the drafters of the APA gave ALJs-but not other agency officials-protection from at-will removal "to render [ALJs] independent and secure in their tenure and compensation." 115 Indeed, even James Madison, a strong proponent of the president's removal power, thought that an administrative adjudicator who presides over hearings in which the United States is a party "should not hold his office at the pleasure of the Executive branch of the Government." 116

110. Buckley v. Valeo, 424 U.S. 1, 126 (1976) (per curiam).

111. Marbury v. Madison, 5 U.S. (1 Cranch) 137, 158 (1803).

112. U.S. CONST. art. II, $\S 3$.

113. Free Enter. Fund v. PCAOB, 561 U.S. 477, 507 n.10 (2010).

114. Heidi Kitrosser, The Accountable Executive, 93 MINN. L. REV. 1741, 1751 (2009).

115. S. REP. NO. 752 (1945), reprinted in APA LEG. HISTORY, supra note 52, at 29. Representative Francis Walter of Pennsylvania noted that his concern that run-of-the-mill civil service protections were "exaggerated" led him to support the more robust protection for ALJs. 79 CONG. REC. (1946), reprinted in APA LEG. HISTORY, supra note 52, at 371.

116. 1 ANNALS OF CONG. 611-12 (1789) (Joseph Gales ed., 1834) (statement of James Madison) (cited in PHH Corp. v. CFPB, 881 F.3d 75, 115 (D.C. Cir. 2018) (Wilkins, J., concurring)). 
The Wiener Court later relied upon an executive official's adjudicatory duties to interpret a statute as limiting the president's at-will removal. In dismissing recent challenges to ALJs' double insulation from at-will removal, lower courts have quickly adopted this adjudicationpolicymaking distinction. ${ }^{117}$

The initial problem with this justification is that it may not distinguish ALJs from the PCAOB members. The Free Enterprise Court framed its holding as applying to an "inferior officer [who] determines the policy and enforces the laws of the United States"118 and stated that the PCAOB members did not exercise adjudicatory functions. ${ }^{119}$ The dissenters responded that the majority decision itself expressly listed the PCAOB members' adjudicatory responsibilities when describing their powers. ${ }^{120}$ Indeed, numerous agency heads, like the PCAOB members, have both adjudicatory and other policymaking authority. ${ }^{121}$

Nonetheless, even if one can meaningfully distinguish between PCAOB members and ALJs by considering adjudicatory or policymaking functions, cleaving adjudication from "policymaking" is exceedingly difficult. As scholars ${ }^{122}$ and the Supreme Court itself have

117. See, e.g., Hill v. SEC, 114 F. Supp. 3d 1297, 1319 n.12 (N.D. Ga. 2015) (declining to resolve the issue but having "serious doubts" about removal provisions' unconstitutionality based on the ALJs' adjudicatory nature), vacated and remanded on other grounds by 825 F.3d 1236 (11th Cir. 2016); Duka v. SEC, 103 F. Supp. 2d 382, 395 (S.D.N.Y. 2015), abrogated on other grounds by Tilton v. SEC, 824 F.3d 276 (2d Cir. 2016). D.C. Circuit Judges Wilkins and Rogers distinguished Free Enterprise Fund by arguing that the "good cause" protection for ALJs, as opposed to the more protective statutory for-cause provision for PCAOB members, permitted the president or department heads to have sufficient supervisory control. PHH Corp., 881 F.3d at 116 n.1 (D.C. Cir. 2018) (Wilkins, J., concurring). The majority in Free Enterprise Fund suggested that the different removal standards might permit distinction. See Free Enter. Fund, 561 U.S. at 502-03, 506. The dissenting justices, however, criticized the majority for failing to make any such suggestion clear. See id. at 537 (Breyer, J., dissenting).

118. Free Enter. Fund, 561 U.S. at 484.

119. See id. at 507 n.10 ("And unlike members of the Board, many administrative law judges of course perform adjudicative rather than enforcement or policymaking functions ....").

120. See id. at 536 (Breyer, J., dissenting); id. at 485 (majority opinion) (discussing PCAOB's authority to "initiate[] formal investigations and disciplinary proceedings" and sanction regulated parties).

121. See Jellum, supra note 19, at 734 (noting that "members of the [PCAOB] performed adjudicative functions" as well as policymaking functions).

122. See generally Charles Koch, Jr., Administrative Judges' Role in Developing Social Policy, 68 LA. L. REV. 1095, 1100-02 (2008) (recognizing that ALJs have "the dual role of applying general agency policy and assuring individual fairness in its application"); Charles H. Koch, Jr., Policymaking by the Administrative Judiciary, 56 ALA. L. REV. 693, 740 (2005) (emphasizing the demands imposed on ALJs based on "[t]he operation of administrative policy development within the administrative adjudicative machinery"). 
recognized,${ }^{123}$ adjudication is simply one method through which agencies make policy. One only need consider the NLRB's longstanding reliance on adjudication for confirmation. ${ }^{124}$ Moreover, all lawful agency action is, and must be, an exercise of the executive power under the separation of powers. Execution of the law occurs via prosecution or enforcement, rulemaking (quasi-legislative power), and adjudication (quasi-judicial power). ${ }^{125}$

Perhaps the Court meant to distinguish those who have final adjudicatory-and thus final policymaking-authority from officials who do not. After all, the Court, in the same breath in which it mentioned the adjudication-based distinction, also indicated that ALJs, unlike PCAOB members, "possess purely recommendatory powers." ${ }^{126}$ But that, too, is troubling. The statutory default under the APA is that ALJs can issue final-not recommended-orders unless the agency provides otherwise in a specific case or by rule across the board. ${ }^{127}$ Numerous non-ALJ adjudicators can also issue final orders. ${ }^{128}$ Moreover, it is far from clear that agencies' use of their discretion to limit ALJs from issuing final decisions in all or specific cases would avoid offending Article II. The Court unanimously held in the nondelegation context that agencies could not cure a separation-ofpowers violation by limiting the power that Congress gave agencies in a statute. ${ }^{129}$ Finally, although courts could distinguish certain ALJs or non-ALJs from the PCAOB members by looking to some kind of actual or possible final-order authority, they will dig themselves into

123. See SEC v. Chenery Corp., 332 U.S. 194, 203 (1947).

124. Amy Semet, An Empirical Examination of Agency Statutory Interpretation, 103 MINN. L. REV. 2255, 2278 (2019).

125. Cf. Morrison v. Olson, 487 U.S. 654, 690 n.28 (1988) (noting the difficulty in defining purely executive, quasi-legislative, and quasi-adjudicative categories, and noting that all of these powers are "executive' at least to some degree").

126. Free Enter. Fund v. PCAOB, 561 U.S. 477, 507 n.10 (2010).

127. 5 U.S.C. $\$ 557(b)$ (2018). See also Darby v. Cisneros, 509 U.S. 137, 152 (1993), which stated:

[I]nitial decisions could become final agency decisions in the absence of an agency appeal. Agencies may avoid the finality of an initial decision, first, by adopting a rule that an agency appeal be taken before judicial review is available, and, second, by providing that the initial decision would be 'inoperative' pending appeal. Otherwise, the initial decision becomes final and the aggrieved party is entitled to judicial review.

(citation omitted) (citing 5 U.S.C. $\$ 557(\mathrm{~b})$ ).

128. See Barnett \& Wheeler, supra note 38, at 53 fig. 16 (detailing what kind of non-ALJs may issue final orders).

129. See Whitman v. Am. Trucking Ass'ns, 531 U.S. 457, 472-73 (2001) (rejecting the argument that an agency can cure an unlawful delegation by limiting its own statutory authority). 
the exact fact-bound, labyrinthine Article II warren that the Lucia Court sought to avoid under the Appointments Clause. ${ }^{130}$

Finally, perhaps the Court meant (or might elect) to exclude "dedicated adjudicators" - those without rulemaking, enforcement, or other policymaking authority-from Free Enterprise Fund's doubleinsulation prohibition. ${ }^{131}$ After all, one plausible distinction between ALJs and non-ALJs, on one hand, and the PCAOB members, on the other hand, is that only the former have a purely adjudicative function. ${ }^{132}$ But an adjudicator-based exception would be inconsistent with the Court's formalist doctrine. The Court's double-insulation prohibition was formal because the Court held that two, but not one, good-cause provisions were problematic without explaining how the second provision materially limited the president's supervisory authority. ${ }^{133}$ In fact, the dissenters explained at length the rarity-if it has ever happened-of the second provision having any effect on the president's supervision. ${ }^{134}$ For the majority, though, the importance of the president's barely or theoretically affected supervisory authority was more important than any perceived benefits from double insulation. ${ }^{135}$ An adjudicator-only exception would exist, however, because it recognizes the functional benefit of limiting the supervisory power to promote impartiality and the functional difference between adjudication in the main and policymaking tools. The benefit of adjudicatory impartiality would trump the rule-based certainty and formality of double insulation. If a functional exception exists for adjudicators under Article II, that exception at the very least conflicts with the Court's separation-of-powers formalism and more problematically undermines the normative force of formalism altogether. ${ }^{136}$

3. Shedding a Tier. If neither Free Enterprise Fund distinction prevails, the most likely outcome is that the Court will sever one of the

130. See supra note 96 and accompanying text.

131. Kevin M. Stack, Agency Independence After PCAOB, 32 CARDOZO L. REv. 2391, 2413 (2011).

132. See id. at 2413-18 (describing scholarship before Free Enterprise Fund that argued for distinguishing dedicated adjudicators from those with other policymaking tools and providing interpretations of Free Enterprise Fund that might support that distinction).

133. Free Enter. Fund v. PCAOB, 561 U.S. 477, 492-508 (2010).

134. Id. at 524-27 (Breyer, J., dissenting).

135. Id. at 498-502 (majority opinion).

136. See Barnett, Standing For, supra note 25, at 674-76 (describing the Court's turn to formalism in its separation-of-powers jurisprudence). 
two tiers that exists for ALJs and numerous non-ALJ adjudicators. As I have discussed at length elsewhere, courts frequently sever offending removal provisions as a cure for Article II violations. ${ }^{137}$ In Free Enterprise Fund itself, the Court severed only one of the two tiers of protections for the PCAOB members. ${ }^{138}$ The virtue of one-tier severance for agency adjudicators is that it provides as much protection from at-will removal as Article II permits under Free Enterprise Fund. Despite its ease and intuitive appeal, that remedy is no panacea.

Assume that the Court, as it did in Free Enterprise Fund with PCAOB, severs the provision that directly precludes the at-will removal of ALJs or non-ALJ adjudicators but leaves the good-cause protection for the MSPB. This outcome creates impartiality problems, especially in agency proceedings in which the agency is a party, because the agency adjudicators are subject to at-will removal and other adverse action. If the adjudicators' agencies can remove them at will, the remaining tier of removal protection for the MSPB becomes meaningless, or nearly so. The MSPB has nothing to review because the agency can remove the adjudicator for any reason or caprice, except perhaps for certain unconstitutional grounds, such as racial discrimination. Moreover, even if the Court took this route, some adjudicators work for independent agencies, like the SEC, and would have two tiers of protection that remain anyway. Severing the independent agency's protection would lead to the end of independent agencies altogether.

Assume this time that the Court severs the MSPB's protection from at-will removal but leaves the adjudicators' immediate protection in place. The outcome helps protect the adjudicators' impartiality in the first instance, but it creates impartiality concerns for the MSPB, whose members the president could not previously remove at will. Atwill removal of the MSPB fundamentally changes the civil service statutory scheme and impacts adjudicators and nonadjudicators alike.

Indeed, the fundamental change to the statutory scheme suggests that severance of the MSPB's insulation protection is an inappropriate response. Severance is inappropriate when it "is evident that the legislature would not have enacted those provisions which are within

137. See Kent Barnett, To the Victor Goes the Toil-Remedies for Regulated Parties in Separation-of-Powers Litigation, 92 N.C. L. REV. 481, 517-27 (2014) (discussing courts' use of severance in separation-of-powers decisions).

138. Free Enter. Fund, 561 U.S. at 508-09. 
its power, independently of that which is not." ${ }^{139}$ Although deciphering legislative intent on severance matters often proves "elusive," 140 severing the MSPB's protection would erase a key innovation of the Civil Service Reform Act of 1978 that altered the preexisting at-will removal that applied to the MSPB's predecessor, the Civil Service Commission. ${ }^{141}$ The Senate Report for the Act, without dissent from the House Report, noted that the protection from at-will removal was meant to "ensure that the [MSPB would] be independent of the direction and control of the president." ${ }^{142}$ In short, the case for severance of the MSPB's protection imperils the entire civil service and offends doctrinal limits on severance.

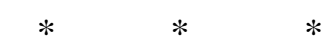

Of course, I have no crystal ball, and I cannot say with any certainty whether the Supreme Court will provide ALJs and other agency adjudicators a carve-out from Free Enterprise Fund's tieredremoval prohibition. It may well be that the Court would find a functional exception to its formalist jurisprudence that considers adjudicators' functions within the executive branch and the competing due process values. Yet the Court's rejection of its proposed officer/employee distinction - in the same footnote in Free Enterprise Fund as the policymaker/adjudicator distinction-only a few years later in Lucia should give one pause. In the meantime, the executive branch can take action to mitigate ill effects from applying Free Enterprise Fund's prohibition to ALJs, or to improve agency adjudication's legitimacy even if the Court places ALJs outside of the prohibition.

139. Buckley v. Valeo, 424 U.S. 1, 108 (1976) (per curiam) (quoting Champlin Refining Co. v. Corp. Comm'n, 286 U.S. 210, 234 (1932)).

140. INS v. Chadha, 462 U.S. 919, 932 (1983).

141. See Frug, supra note 23, at 955 (citing Act of Jan. 16, 1883, ch. 27, pmbl., 22 Stat. 403). The main debate between the House and the Senate concerned whether the Director of OPM, not the MSPB, should have protection from the president's at-will removal. Congress deleted the protection for the OPM director but sought to provide a measure of independence by providing him or her a four-year term. See H.R. CONF. REP. No. 95-1717, at 132 (1978), as reprinted in 1978 U.S.C.C.A.N. 2860, 2865-66; see also 5 U.S.C. \$1102(a) (2019) (imposing no for-cause requirement for removal).

142. S. REP. NO. 95-969, at 28 (1978), as reprinted in 1978 U.S.C.C.A.N. 2723, 2750. 


\section{INTERNAL SEPARATION OF POWERS}

Internal separation of powers or functions within the executive branch provides an alternative solution to the agency-adjudicator dilemma. Competition among the branches-through separation of powers or checks and balances-creates "friction" to improve governmental decision-making. ${ }^{143}$ But interbranch competition is often absent, whether because the separation of branches has become a separation of political parties: ${ }^{144}$ Congress has delegated significant authority to the executive; ${ }^{145}$ or judicial doctrines limit nuanced, functional interactions among the branches. ${ }^{146}$ When branches will not or cannot limit one another, ${ }^{147}$ one branch may find it beneficial to limit its own authority by creating its own friction. ${ }^{148}$ For instance, the judiciary may find it wise to rely on self-imposed prudential doctrines - such as ripeness, primary jurisdiction, or abstention - that delay or avoid decision-making altogether. Or the Senate may use the self-imposed filibuster to require supermajorities for passing bills. Or, as is most relevant here, the executive can and frequently does use numerous internal devices, including those related to removing executive officials, to improve its decision-making.

As this Part discusses, these internal devices within the executive branch-often referred to collectively as "internal administrative law" - can regulate agency personnel in numerous ways. One way includes establishing internal separation of powers to create some independence for agency officials, including adjudicators, from partisan reprisal. In fact, the executive branch has a long-standing, yet perhaps overlooked, history of providing civil service protections to

143. Neal Kumar Katyal, Internal Separation of Powers: Checking Today's Most Dangerous Branch from Within, 115 YALE L.J. 2314, 2317 (2006).

144. See generally Daryl J. Levinson \& Richard H. Pildes, Separation of Parties, Not Powers, 119 HARV. L. REV. 1 (2006) (arguing that the Founders' version of separation of powers has been replaced by competition between political parties, whereby the branches largely compete only when the parties do).

145. See Katyal, supra note 143, at 2319 (discussing the Authorization for Use of Military Force Act and the USA PATRIOT Act after the 9/11 terror attacks).

146. See generally Leah M. Litman, Debunking Antinovelty, 66 DUKE L.J. 1407 (2017) (arguing against the judicial inclination that novel statutory provisions that seek to address new problems violate separation-of-powers or federalism principles).

147. For a recent discussion of how Congress imposes "statutory separation of powers" on the executive in the energy-regulation sphere, see generally Sharon B. Jacobs, The Statutory Separation of Powers, 129 YALE L.J. 378 (2019).

148. Katyal, supra note 143 , at 2317. 
improve the professionalism of executive officials through internal administrative law.

\section{A. Separation of Powers via Internal Administrative Law}

Internal administrative law, in its purest form, concerns mechanisms or norms that originate from "within the agency or the executive branch ... that speak primarily to government personnel."149 It can both limit and empower agencies, ${ }^{150}$ and fill an important regulatory void. For instance, Professors Gillian Metzger and Kevin Stack argue that judicial control over agencies will never be sufficient

to ease anxieties about the administrative state or successfully regulate the exercise of administrative power. Instead, core internal features of agencies-such as management structures, guidance, planning and coordination, civil service, professionalism, and the like - need to be recognized as central to administrative law, as they once were in administrative law's early years. ${ }^{151}$

In other words, internal administrative law is a useful, even if sometimes forgotten, instrument for improving bureaucratic decisionmaking and promoting legitimacy within a democratic government.

Internal administrative law can further many objectives. It can promote presidential control and efficiency, as then-Professor Elena Kagan argued in her prominent commendation of centralized presidential administration. ${ }^{152}$ Nevertheless, she recognized that good government needs more than centralization and efficiency. ${ }^{153}$ Picking up where Kagan left off, then-Professor Nina Pillard argued that the president should instruct agencies not to aggrandize executive authority at every opportunity and instead seek to protect private rights. ${ }^{154}$ Doing so can reduce constitutional tensions and avoid normatively unattractive results. ${ }^{155}$ Pillard noted that the power of internal administrative law and executive-made constitutional law

149. Gillian E. Metzger \& Kevin M. Stack, Internal Administrative Law, 115 MICH. L. REV. 1239,1251 (2017).

150. Id. at 1248 .

151. Id. at $1246-47$.

152. Elena Kagan, Presidential Administration, 114 HARV. L. REV. 2245, 2339-41 (2001).

153. See, e.g., id. at 2352-58 (discussing the utility of expertise); id. at 2342-44 (discussing checks and balances).

154. Cornelia T. L. Pillard, The Unfulfilled Promise of the Constitution in Executive Hands, 103 MiCH. L. REV. 676, 745 (2005).

155. Id. at $749-51$. 
permit the executive branch "unilaterally to increase its vigilance against rights violations." ${ }^{156}$ Executive action that curtails individual rights, in contrast, requires judicial approbation. ${ }^{157}$ In fact, during the Franklin D. Roosevelt administration, the Attorney General's Committee on Administrative Procedure highlighted how internal administrative law could protect private rights, especially in the absence of judicial review. ${ }^{158}$

One flavor of internal administrative law is internal separation of powers. Although internal administrative law may often connote a mechanism for promoting centralized policymaking, as Kagan suggested,${ }^{159}$ the executive can also use it to make it harder to control particular outcomes. Internal separation of powers disrupts absolute hierarchical control over personnel or decision-making within one agency or the entire executive branch. It may pit the executive bureaucracy against other bureaucrats or political appointees, or protect one group from another. ${ }^{160}$

Many of the mechanisms for internal separation of powers are familiar and demonstrate the ways in which the executive-alone or with Congress - has limited its ability to act. Professor Neal Katyal identifies "separate and overlapping cabinet offices, mandatory review of government action by different agencies, civil-service protections for agency workers, reporting requirements to Congress, and an impartial decision-maker to resolve inter-agency conflicts." 161 Other tools include the Department of State's "Dissent Channel." This channel permits diplomatic officials to express disagreement with official position and obtain a response. ${ }^{162}$ But even less formal independence can be useful. The day-to-day, de facto freedom that the solicitor general has from the president and the attorney general gives her the

156. Id. at 682 .

157. Id.

158. See Metzger \& Stack, supra note 149, at 1274 ("Even in the sphere in which judicial review is available important private interests must still be left to the practically unreviewable judgment of the administrative tribunals and reliance be placed on other controls for the fair exercise of that judgment." (quoting ATTORNEY GEN.'s COMM. ON ADMIN. PROCEDURE, FINAL REPORT 77 (1941))).

159. Kagan, supra note 152, at 2316, 2384.

160. See Katyal, supra note 143, at 2317 (explaining that internal separation of powers creates friction and results in better decision-making).

161. Id. at 2318 .

162. U.S. DeP'T OF STATE, 2 Foreign AfFairs MANual $\$ \S 070-075$ (2018), https://fam.state.gov/searchapps/viewer?format=html\&query=dissent $\% 20$ channel\&links=DISS ENT,CHANNEL\&url=/FAM/02FAM/02FAM0070.html\#M072 [https://perma.cc/7JEF-Q9W5]. 
ability to consider the long-term interests of the executive branch and cultivate authority and credibility with the courts. ${ }^{163}$

Internal separation of powers, as well as other forms of internal administrative law, are consistent with the formal unitary executive theory that has gained prominence in conservative legal circles. ${ }^{164}$ Under that theory, "all federal officers exercising executive power must be subject to the direct control of the President." 165 This theory is deeply suspicious of congressional attempts to limit presidential control. The theory further divides itself into subtheories that require-from strongest to weakest-direct presidential control over all executive decisions, the president's authority to nullify an officer's discretionary decision, or presidential power to fire any principal executive officer at will. ${ }^{166}$ Because internal administrative law can be self-imposed - that is, without Congress - constitutional separation-ofpowers concerns fall away. No other branch is interfering with executive authority. Relatedly, because the president or agency heads retain the authority to reverse earlier internal executive actions in nearly all cases, ${ }^{167}$ one president cannot bind a later one. ${ }^{168}$ Because self-limiting actions do not implicate the constitutional separation of powers, the Supreme Court has stated that " $\mathrm{t}]$ he President can always choose to restrain himself in his dealings with subordinates." 169

163. See Pillard, supra note 154, at 705 (citing 28 U.S.C. $\$ 505$ (2000)); id. at 707 (citing 28 C.F.R. $\$ 0.135$ (2004)); id. at 726-33. This is not to say that political actors never intervene in the solicitor general's decision-making. See id. at 707 n.94 (describing various ways in which the solicitor general's superiors in the Justice Department may involve themselves in litigation strategies).

164. See generally Stephen Skowronek, The Conservative Insurgency and Presidential Power: A Developmental Perspective on the Unitary Executive, 122 HARV. L. REV. 2070 (2009) (discussing how the conservative political movement has turned to the unitary executive as a political tool since the 1970s).

165. Steven G. Calabresi \& Kevin H. Rhodes, The Structural Constitution: Unitary Executive, Plural Judiciary, 105 HARV. L. REV. 1153, 1158 (1992).

166. See Kitrosser, supra note 114, at 1746.

167. One president can repeal an earlier president's executive order. See Richard H. Seamon, Dismantling Monuments, 70 FLA. L. REV. 553, 588 (2018). Likewise, agencies can repeal an earlier administration's regulations by using the same process that the agency used to promulgate them in the first instance. See, e.g., 5 U.S.C. \$ 551(5) (2018) (defining "rule making" as "formulating ... or repealing a rule"); id. $\S 553$ (providing requirements for substantive and other forms of rulemaking); see also FCC v. Fox Television Stations, Inc., 556 U.S. 502, 514-15 (2009) (noting that agencies need not demonstrate that the repealed rule is better than the previous rule, but agencies may have to account for strong reliance interests).

168. See Free Enter. Fund v. PCAOB, 561 U.S. 477, 497 (2010) ("[The president] cannot ... choose to bind his successors by diminishing their powers ....").

169. Id. at 497. 
To be sure, compared to statutory administrative law, internal administrative law's significant disadvantage is that it has less permanence and permits easier repeal. Yet agencies can create more regulatory permanence by using notice-and-comment procedures for the promulgation, amendment, or repeal of internal rules. ${ }^{170}$ Unless repealed, the regulations would likely have the force of law. For instance, when President Nixon challenged a subpoena by a special prosecutor whom the attorney general appointed per executive regulations, the Court stated in dicta: "So long as this regulation [that bestows power on the special counsel] remains in force the executive branch is bound by it, and indeed the United States as the sovereign composed of the three branches is bound to respect and to enforce it." ${ }^{171}$ Internal administrative law that requires a transparent process for amendment or repeal provides a "credible commitment" of the agency's self-restraint because agencies must follow their own internal rules. ${ }^{172}$

\section{B. Protecting Officials from At-Will Removal}

Internal separation of powers has an established, though perhaps largely forgotten, provenance in insulating the federal bureaucracy. The development of the civil service has been the subject of many tomes, articles, and government reports. My purpose here is to demonstrate briefly internal separation of powers' significant role in developing the service's protections from at-will removal.

Presidents have rarely exercised their powers of at-will removal over lower-level bureaucrats. In the Decision of 1789, Congress decided - by a decisive vote in the House and one vote in the Senatethat impeachment was not the exclusive means of removing federal officials: the president could also remove them. ${ }^{173}$ However, executiveled removal of civil servants remained extremely rare in the decades

170. See 1 Richard J. Pierce, JR., Administrative LAW Treatise $§ 7.10$, at 669 (5th ed. 2010).

171. United States v. Nixon, 418 U.S. 683, 696 (1974); accord United States ex rel. Accardi v. Shaughnessy, 347 U.S. 260, 267 (1954).

172. Metzger \& Stack, supra note 149, at 1284 (citing Elizabeth Magill, Foreword, Agency Self-Regulation, 77 GEO. WASH. L. REV. 859, 873-74 (2009)). The Supreme Court has not resolved the long-standing question as to whether agencies are bound to both their legislative rules and their nonlegislative guidance, or only the former. Lower courts have come out both ways. See id. at 1285-86.

173. See Frug, supra note 23, at 949. 
following the Founding and usually only involved removals for cause. ${ }^{174}$ In fact, presidential behavior did not change even when Congress enacted the Tenure of Office Act of 1820 to render it easier for the president to remove federal officials. ${ }^{175} \mathrm{By}$ imposing fixed, four-year terms for many federal officials and clarifying the president's ability to remove them at will, Congress sought to limit any inference that removal impugned the character of the officials. Nonetheless, presidents did not take advantage of their authority to fire existing federal employees at the end of their statutory four-year terms. Instead, they routinely reappointed employees to additional terms. ${ }^{176}$ The well-known spoils system-of replacing existing officials with loyalists - did not begin with gusto until the Jackson administration. Yet even President Jackson limited his spoils system to approximately 20 percent of the federal bureaucracy. ${ }^{177}$

Contemporaries recognized the spoils system as a suboptimal bureaucratic system during its heyday, ${ }^{178}$ but it was likely a necessary step to bureaucratic maturity. Noted political scientist Francis Fukuyama argues that what Americans commonly refer to as a spoils system is, in fact, "clientelism," whereby politicians award jobs and other benefits to supporters on a large, well-organized scale. ${ }^{179}$ Clientelism occurs as a frequent step in democratic maturity as politicians endeavor to command majority-voting blocks. Numerous countries bear witness. ${ }^{180}$ Indeed, clientelism may be especially democratic in the sense that the election of a president indicates the public wants a change in the on-the-ground bureaucratic

174. See id. at 949-50 ("[F] or the first thirty years of the country's history, with the exception of Jefferson's attempt to modify the political balance of the government work force, removals were rare, and those made were for cause.").

175. Act of May 15, 1820, ch. 102, 3 Stat. 582.

176. See Frug, supra note 23, at 950-51.

177. See id. at 951-52; see also Farkas v. Thornburgh, 493 F. Supp. 1168, 1170 n.6 (E.D. Pa. 1980) ("Although some historians trumpet Jackson's pervasive endorsement and exploitation of patronage, actually Jackson removed no more than one-tenth to one-fifth of the previously appointed federal service.").

178. See Farkas, 493 F. Supp. at 1170 n.8 (discussing nineteenth-century criticism of the patronage system). An office seeker's assassination of President Garfield created an impetus for reforming civil service selection and enacting the Pendleton Act. See William R. Sherman, $A$ Pragmatic Republic, If You Can Keep It, 112 MiCH. L. REV. 905, 914 (2014).

179. See Francis FukuYAma, Political ORder AND POLITICAL DECAY 86 (2014).

180. See id. at 91-93 (noting that clientelism is a manner of mobilizing voters in early democracies; that Taiwan and the United States have turned away from it; and that Italy, Japan, and Greece still have forms of clientelism). 
administration. ${ }^{181}$ But what clientelism does to enrich democratic accountability can undermine the bureaucracy's ability to work in a fair, impartial, and efficient way-just ask Greece and Italy. ${ }^{182}$

As the federal bureaucracy and national economy became more complex after the Civil War, Congress enacted statutes to render the bureaucracy more professional. In one of its first efforts, ${ }^{183}$ Congress passed the Pendleton Act of 1883, creating a competitive examination process for hiring civil servants. ${ }^{184}$ The Act, however, neither required the president to hire based on the examination scores nor regulated the president's removal authority. ${ }^{185}$ Instead, it merely permitted the president to use the Civil Service Commission to administer the examination, as opposed to relying upon political-party bosses. ${ }^{186}$ Removal protections were thought unnecessary because the president would have little incentive to remove if a merit system, not patronage, governed new hires. ${ }^{187}$

Professor Gerald Frug has demonstrated that the executive, not Congress, became the driving force behind the push to limit the president's removal authority during the bureaucracy's expansion at the turn of the twentieth century. ${ }^{188}$ The executive agency charged with overseeing the civil service, the Civil Service Commission, had asked President Cleveland to issue an executive order that would require a removing official to provide the reason for removal and include it in departmental records. ${ }^{189}$ Although Cleveland declined to do so, ${ }^{190}$

181. See CARl Russell Fish, The Civil SERvice AND THE PATronage 42 (1904); id. at 78 ("[W]hen the people voted in 1828 that John Quincy Adams should leave office, they undoubtedly intended to vote that most of the civil servants should go with him.").

182. See generally FUKUYAMA, supra note 179, at 94-134 (describing how old forms of clientelism in Italy and Greece led to the Italian and Grecian financial crises in the 2000s).

183. The Tenure of Office Act of 1867 was not aimed so much at improving the working of the bureaucracy but as limiting the ability of President Johnson to remove officials without the Senate's approbation. See Frug, supra note 23, at 952-53.

184. Act of Jan. 16, 1883, ch. 27, § 2, 22 Stat. 403.

185. See Frug, supra note 23, at 954-55.

186. See id.

187. See id. at 955. Professor Jennifer Mascott suggests that the Supreme Court has intimated a similar, yet inverse, relationship in Morrison v. Olson, 487 U.S. 654 (1988): the more control that the executive has over appointment, the less control the executive needs over removal. See Mascott, supra note 56, at 38-39.

188. See generally Frug, supra note 23, at 947-61 (describing the history of the civil service and the presidential power to remove, especially how presidents would limit removal power through executive orders).

189. See 15 U.S. CIV. SERV. COMM'N ANN. REP. 19 (1899).

190. See Frug, supra note 23, at 956. 
President McKinley did. In fact, McKinley went even further, ordering that "[n]o removal shall be made from any position subject to competitive examination except for just cause and upon written charges filed with the head of the department or other appointing officer, and of which the accused shall have full notice and an opportunity to make defense." ${ }^{191}$ McKinley, accordingly, required "just cause" for removal from the competitive civil service and provided, at the very least, internal process for the employee at issue.

To assuage the Commission's concern that fired officials could obtain a trial over the reason for their removal under McKinley's order, Presidents Theodore Roosevelt and William Taft clarified in executive orders that notice and opportunity to be heard provided only the right to reply to one's agency superiors before removal. ${ }^{192}$ Roosevelt's order also clarified that "just cause" for removal "was intended to mean any cause, other than one merely political or religious, which will promote the efficiency of the service." Employees had no right to judicial review of their superior's absolute discretion to determine when sufficient cause existed for removal. ${ }^{193}$

Starting around the time of the Roosevelt and Taft orders, Congress took a series of uneven actions on the removal front. First, it codified in the Lloyd-LaFollette Act of 1912 the "efficiency of the service" standard and the right of employees to respond to their agency superiors found in the earlier presidential orders. ${ }^{194}$ Second, in the Veterans' Preference Act of 1944, Congress extended additional rights to veterans by allowing them to challenge their removal in an oral hearing and to seek review from the Civil Service Commission. ${ }^{195}$ Third, in 1946 Congress created the office of ALJs (then called "hearing examiners") and limited ALJs' removal "only for good cause established and determined by the Civil Service Commission ... after opportunity for hearing and upon the record thereof." ${ }^{196}$ The

191. 14 U.S. CiV. SERV. COMM’N ANN. REP. 24 (1898).

192. See Frug, supra note 23, at 956-58.

193. See id. at 957 (quoting 19 U.S. CIV. SERV. COMM'N ANN. REP. 76 (1902)).

194. See id. at 958 (citing Act of Aug. 24, 1912, ch. 389, § 6, 37 Stat. 555 (codified as amended at 5 U.S.C. $\$ \S 7101,7102$ (1970)). The relevant language permitted only removal with "such cause as will promote the efficiency of [the civil] service," and the statute granted only a right to written reasons and a written opportunity to respond. $\$ 6,37$ Stat. 555.

195. See Frug, supra note 23, at 959.

196. Administrative Procedure Act, Pub. L. 79-404, ch. 324, § 11, 60 Stat. 237, 244 (1946) ("Examiners"). 
incongruity of review for different federal employees led to calls for a uniform system. ${ }^{197}$

The executive, not Congress, initially responded. President Kennedy established administrative appeals within each agency for adverse employment actions and granted all employees a right to an oral hearing. President Nixon went further. He granted nonveterans the same right that veterans had to appeal to the Commission and later abolished the Kennedy-era appeals within each agency. ${ }^{198}$ These executive-led improvements culminated in the Civil Service Reform Act of 1978 ("CRA"), ${ }^{199}$ which Congress enacted largely to restore eroded trust in the federal government after Watergate. ${ }^{200}$ Among numerous other things, the CRA abolished the Commission and created two agencies to assume its functions: OPM would largely oversee hiring and personnel management, while the MSPB would, among other things, review agency-imposed removals and discipline. ${ }^{201}$

In summary, the story of insulating executive officials from at-will removal is largely one of executive invention and impetus, followed by eventual congressional codification of many of the executive-imposed personnel measures.

\section{IMPARTIALITY REGULATIONS}

Internal separation of powers is extremely beneficial to agency adjudicators. Justice Breyer recognized in his Free Enterprise Fund dissent that "sometimes it is necessary to disable oneself ... to achieve a broader objective. ... If the President seeks to regulate through impartial adjudication, then insulation of the adjudicator from removal at will can help him achieve that goal." 202 A subordinate decisionmaker's "neutrality might inspire confidence," according to Professor Katyal, "both in the public eye and in the courts, in a way that political decisions could not." ${ }^{203}$ Internal administrative law for adjudication-

197. See Frug, supra note 23, at 960.

198. See id. at 961.

199. Civil Service Reform Act of 1978, Pub. L. No. 95-454, 92 Stat. 1111.

200. See Julie Jones, Give A Little Whistle: The Need for a More Broad Interpretation of the Whistleblower Exception to the Employment-at-Will Doctrine, 34 TEX. TECH L. REV. 1133, 1141 (2003).

201. See Earl Sanders, 5 U.S.C. $\S 7703(d)$ : The Civil Service Commission Did Not Fade Away-Entirely, 31 How. L.J. 197, 199 (1988); About, U.S. MERIT SYSTEM PROTECTION BOARD, https://www.mspb.gov/About/about.htm [https://perma.cc/AA3D-DYHY].

202. Free Enter. Fund v. PCAOB, 561 U.S. 477, 522 (2010) (Breyer, J., dissenting).

203. Katyal, supra note 143 , at 2335. 
via regulation and executive order, or collectively, "impartiality regulations"-can achieve these purposes without offending the constitutional separation of powers. Indeed, Professor Daniel Rodriguez advocates for leaving matters of bias to agencies to regulate themselves, given the difficulty of having courts fashion doctrine to address various forms of bureaucratic bias, different kinds of decisionmakers, and disparate types of decisions. ${ }^{204}$ And Professor Jennifer Nou similarly suggests that courts "are not well-placed to adjudicate decisional independence claims [asserted by ALJs concerning agency oversight or interference], which are at their root managerial questions requiring political tradeoffs." 205 Impartiality regulations allow agencies to address matters that are, in Nou's words, "internal to [the] agenc[y] and the executive branch," ${ }^{206}$ while recognizing that these internal matters can impact both private parties and public perception.

This Part proposes adopting impartiality regulations to govern agency adjudicators of all stripes. Section A considers how the executive branch can design and implement such impartiality regulations. The regulations that establish and protect the Office of the Special Counsel provide a useful template. But the impartiality regulations would have to clarify to whom they apply specifically, and they should be promulgated through notice-and-comment process to establish as firm a commitment to impartiality as possible from the executive branch. Section B then considers how the impartiality regulations should address adjudicators' discipline and removal, meritbased hiring, and other provisions that provide indicia of impartiality. Section $\mathrm{C}$ concludes by considering potential concerns or skepticism over impartiality regulations as a useful form of internal administrative law.

\section{A. Designing and Implementing Impartiality Regulations}

In designing impartiality regulations, the executive branch need not start from scratch. The Department of Justice already has regulations that establish the office and independence of the special counsel. These Special Counsel Regulations ("SCRs") provide a

204. Daniel B. Rodriguez, Bias in Regulatory Administration, 70 CASE W. RES. L. REV. (forthcoming 2020) (manuscript at 76), https://papers.ssrn.com/sol3/papers.cfm?abstract_id= 3430809 [https://perma.cc/RY4U-H24T].

205. Jennifer Nou, Dismissing Decisional Independence Suits, 86 U. CHI. L. REV. 1187, 1189 (2019).

206. Id. 
template for adjudicatory impartiality regulations, although the impartiality regulations should depart from some of the SCRs' particulars. With a template in hand, the executive branch should next grapple with how to identify the adjudicators to whom the impartiality regulations would apply. Finally, before diving into the substance of the impartiality regulations, the executive drafters should consider the appropriate process and form for implementing their impartiality regulations.

1. The Special Counsel Regulations as a Template. In brief, the SCRs concern the grounds for appointing a special counsel, his or her qualifications, jurisdiction, staffing, powers, reporting requirements, and removal from office. ${ }^{207}$ As most relevant to adjudicator impartiality, the regulations provide that the attorney general can remove the special counsel "for misconduct, dereliction of duty, incapacity, conflict of interest, or for other good cause, including violation of Departmental policies." ${ }^{208}$ These regulations have governed the appointments of special counsels John Danforth when reviewing the FBI's conduct in the Waco, Texas, siege and, most recently, Robert Mueller when investigating Russian interference in the 2016 presidential election. ${ }^{209}$

The SCRs filled a void when Congress declined to revive the Office of the Independent Counsel following expiration of the Ethics in Government Act. That Act was widely criticized for bestowing too much power on the independent counsel. ${ }^{210}$ And although the Supreme Court held the Office of the Independent Counsel is constitutional in Morrison v. Olson ${ }^{211}$ several legal scholars have found Justice Scalia's lone dissent-raising various constitutional separation-of-powers issues - to be both prescient and convincing. ${ }^{212}$ Katyal sought to avoid repeating the mistakes of the past when he drafted the SCRs during the Clinton administration, noting that they cabin the special counsel's

207. See generally General Powers of Special Counsel, 28 C.F.R. §§ 600.1-600.10 (2019).

208. Id. §600.7(d).

209. See Cynthia Brown \& Jared P. Cole, Cong. Research Serv., R44857, Special COUNSEl INVESTIGATIONS: HisTORY, AUTHORITY, APPOINTMENT AND REMOVAL 8-9 (2019) (discussing past special counsel investigations). The appointment of Patrick Fitzgerald to investigate the leaking of a CIA operative's identity did not occur under the regulations. See id. at 9 .

210. See id. at 8 .

211. Morrison v. Olson, 487 U.S. 654 (1988).

212. See id. at 24-25. 
investigatory discretion but still removed the special prosecutors from "the day-to-day control and influence of political actors." 13

The impartiality regulations can serve a similar purpose as the SCRs. Both are internal devices that the executive branch can use to preserve useful schemes in the face of legislative silence, constitutional question, and pragmatic concern. Both separate a small subset of executive officials with sensitive duties from "day-to-day supervision of any official of the [agency]" ${ }^{214}$ while permitting executive superiors to retain final policymaking authority. The SCRs promote nonpolitical investigations of sensitive matters or conflicted executive actors, and the impartiality regulations provide the appearance of an impartial forum and thereby impart legitimacy to executive decision-making.

2. Defining "Adjudicators." The regulations would need to first identify the covered adjudicators. Including ALJs is easy because their uniform, statutory-based status makes them easy to identify. ${ }^{215}$ NonALJ adjudicators, however, prove more difficult to identify because of their disparate titles and diverse roles. Nevertheless, the Administrative Conference of the United States ("ACUS")- the independent agency charged with providing research and recommendations to federal agencies and Congress - has provided two workable definitions.

First, non-ALJ adjudicators could be those who preside over what Professor Michael Asimow terms "Type B"-as opposed to "Type A"-adjudications. Type A adjudications include only those that are "required by statute to be determined on the record after opportunity for an agency hearing." ${ }^{216}$ In other words, Type A hearings are those over which ALJs preside and which are governed by $\S \S 554,556$, and 557 of the APA. ${ }^{217}$ Type B hearings, in contrast, concern "agency adjudication that employ evidentiary hearings required by statutes,

213. Katyal, supra note 143 , at 2338.

214. 28 C.F.R. $\$ 600.7$ (b) (2019).

215. See, e.g., 5 U.S.C. $\S \S 554,556,3105$ (2018) (provisions that expressly consider "administrative law judges").

216. Michael Asimow, Best Practices for Evidentiary Hearings Outside the Administrative Procedure Act, 26 GEO. MASON L. REv. 923, 937 (2019) (emphasis omitted) (quoting 5. U.S.C. $\S 554(\mathrm{a}))$.

217. See 5 U.S.C. $§ 554$ (a) (providing the "on the record after opportunity for an agency hearing" trigger for Type A adjudication). 
regulations, or executive orders, but are not governed by the formal adjudication provisions of the APA." 218

Second, non-ALJ adjudicators could fall within a broader definition to include those who are not ALJs or members of the agency, but nonetheless preside over hearings in which parties may opt for an oral, evidentiary hearing under statute, regulation, or other law. ${ }^{219}$ This broader definition would capture elected-but not mandatoryadjudications and executive officials who may only rarely oversee evidentiary hearings, such as patent examiners. By excluding members of the agency, such as agency heads and commissioners, the impartiality regulations maintain the traditional and APA-based distinction between lower-level adjudicators and agency heads.

3. Implementing Impartiality Regulations. To implement the impartiality regulations, the executive branch should take a two-prong approach. Justice Kagan noted that "the President has the ability to effect comprehensive, coherent change in administrative policymaking." 220 To that end, the president should issue executive orders to all agencies, including independent agencies, at those independent agencies' election. The order would provide a template set of notice-and-comment regulations for agencies to promulgate for those agency adjudicators who fall within the order's ambit, but it would provide discretion to individual agencies to account for any necessary revisions for a particular adjudicatory scheme or enabling act. The executive order should ensure that the impartiality regulations permeate the administrative state and apply to both ALJs and nonALJ adjudicators. The promulgation of rules pursuant to executive order for each agency can find statutory basis in the $\mathrm{APA}^{221}$ and traditional notions of administrative common law. ${ }^{222}$

Agencies should agree to use notice-and-comment procedures under 5 U.S.C. $\S 553$ for any rulemaking-whether promulgation,

218. Asimow, supra note 216 , at 925.

219. See Barnett \& Wheeler, supra note 38, at 25 (providing a more detailed definition).

220. Kagan, supra note 152 , at 2341.

221. 5 U.S.C. $\$ 559$ ("Each agency is granted the authority necessary to comply with the requirements of this subchapter through the issuance of rules or otherwise.").

222. See Vt. Yankee Nuclear Power Corp. v. Nat. Res. Def. Council, Inc., 435 U.S. 519, 52425 (1978) (establishing that courts cannot generally impose additional procedure beyond a statute's requirements on agency decision-making); 1 KENNETH CULP DAVIS, ADMINISTRATIVE LAW TREATISE $\$ 8.02$, at 519 (1958) (noting that the APA promoted uniformity only as to minimal requirements). 
amendment, or repeal ${ }^{223}$ - concerning impartiality regulations. It is true that agency management and personnel matters are excluded from notice-and-comment rulemaking requirements under $\S 553 .{ }^{224}$ Generally, the process is less useful for matters that are merely internal to the agency and thus do "not affect ... the public." 25 But agencies can and often do elect to use notice-and-comment process, even if the matter at issue falls under an exemption. ${ }^{226}$

For impartiality regulations, the notice-and-comment process is beneficial in three ways. First, the process may prove useful because regulated parties have a direct interest in the fairness of agency proceedings. Second, the process, by engaging the public, is likely to render the impartiality regulations more salient, which is useful for matters related to the appearance of impartiality. Finally, the use of notice and comment for any amendment or repeal would render any change much more transparent, help create a more developed record for judicial review, and establish a more meaningful-and potentially longer-lasting-executive commitment. The agency should commit to using notice and comment for any amendment or repeal to create as much regulatory permanence as possible.

\section{B. The Substance of the Impartiality Regulations}

The impartiality regulations would depart from the SCRs in their particulars. They would not focus on authority and notifications. Instead, the impartiality regulations would focus on three key areas: discipline and removal, merit-based appointment, and additional indicia of separation from the agency.

1. Discipline-and-Removal Provisions. To resolve any due process concern over adjudicators' protection from at-will discipline or removal, the regulations should duplicate ALJs' current statutory

223. 5 U.S.C. $§ 551(5)$ (defining "rule making" to include the formulation, amendment, or repeal of a "rule").

224. 5 U.S.C. $\$ 553(\mathrm{a})(2)$. The SCRs were not promulgated with notice and comment. BROWN \& COLE, supra note 209, at 20 (citing Office of Special Counsel, 64 Fed. Reg. 37,038, 37,041 (July $9,1999))$.

225. TOM C. Clark, Dep'T of Justice, AtTorney General's MANuAl on the Administrative Procedure ACT 18 (1947).

226. See 1 PIERCE, supra note 170, § 7.10, at 669 (noting that agencies have voluntarily adopted notice-and-comment rulemaking, despite statutory exemptions); see also Public Participation in Rulemaking, 36 Fed. Reg. 13804 (July 24, 1971) (discussing the advantages of implementing the recommendation of the ACUS to require notice and comment, even when exempted by statute). 
protection from at-will adverse action for all agency adjudicators ${ }^{227}$ as follows:

An agency may not take a covered action, as defined herein, against an adjudicator unless the Merit Systems Protection Board determines that good cause exists on the record after opportunity for a hearing before the Board.

The "covered actions" could simply duplicate those listed as applying to ALJs, such as removals, suspensions, and reductions in pay. ${ }^{228}$ Notably, this regulation does not alter current protections for the entire civil service, but it does ensure that all lower-level adjudicators - not just ALJs - receive sufficient administrative process before an independent agency disciplines or removes them. It also provides all covered agency adjudicators with the same level of protection by granting the non-ALJs the more robust form of protection that ALJs currently enjoy. ${ }^{229}$ Adjudicators' shared function and need for impartiality justify uniform removal protection. ${ }^{230}$

The impartiality regulations go further than the SCRs by giving agency adjudicators, unlike the special counsel, a right to a formal administrative hearing and judicial review. Echoing earlier civil service regulations, the SCRs attempt to prevent all review by stating that the regulations do not create any rights that could be subject to judicial review. ${ }^{231}$ The impartiality regulations would not do so. Instead, they would seek to demonstrate a strong commitment from the executive branch for impartial adjudicators by permitting administrative and judicial review. This commitment exists because the president or

227. 5 U.S.C. $\$ 7521$.

228. Id. § 7521(b).

229. See supra note 85 and accompanying text.

230. Many, if not most, non-ALJ adjudicators are hired for a probationary period. See 5 C.F.R. § 315.801 (2019) (OPM regulation: "Probationary period; when required"). Unless a statute requires otherwise for particular non-ALJs, the regulation should not subject them to probationary periods because of the control that it gives the agency over the adjudicator's livelihood.

231. 28 C.F.R. $§ 600.10$ (2019) ("No creation of rights. The regulations in this part are not intended to, do not, and may not be relied upon to create any rights, substantive or procedural, enforceable at law or equity, by any person or entity, in any matter, civil, criminal, or administrative."). The courts "have generally not ... recognized [the SCRs] as creating judicially enforceable rights." BROWN \& COLE, supra note 209, at 20. The Office of Management and Budget included a similar no-rights provision in its "Final Bulletin for Agency Good Guidance Practices," which established policies for developing guidance documents through executive agencies. See Metzger \& Stack, supra note 149, at 1288 (referring to OfFICE OF MGMT. \& Budget, EXeC. OfFice of the PREsident, OMB Bull. No. 07-02, FinAl Bulletin For AgenCy Good GuidanCE PRACTICES, 72 Fed. Reg. 3432, 3437, 3440 (Jan. 25, 2007)). 
agency cannot, consistent with United States $v$. Nixon, ${ }^{232}$ simply ignore the regulations by disciplining adjudicators at will or without review as long as the regulations are in effect. Unlike special counsels, who have high political salience, agency adjudicators do not have significant public visibility and potential political protection from interference. The regulatory protection and right to seek review protect the more vulnerable adjudicators.

Neither administrative nor judicial review requires any congressional action. The MSPB has broad jurisdiction to adjudicate matters referred to it by regulation or rule. ${ }^{233}$ All orders from the MSPB, in turn, are subject to deferential judicial review. ${ }^{234}$

Notably, impartiality regulations resolve the agency-adjudicator dilemma. They provide a prophylactic device-limiting at-will discipline or removal-for protecting impartiality. Indeed, the presence or lack of at-will removal is the device for presidential control that the Court has featured in its Article II jurisprudence. At the same time, because the executive branch imposes the protection from at-will removal from within, it does not implicate Free Enterprise Fund's prohibition or any other form of impermissible congressional limitation on presidential supervision.

By permitting the MSPB to establish when cause exists, the impartiality regulations render it unnecessary to consider the Department of Justice's current view that could render good-cause removal toothless. As part of his briefing in Lucia and subsequent cases, Solicitor General Noel Francisco asserted that the tiered protection from at-will removal for ALJs is constitutional as long as "good cause" permits removal for any "ALJ who fails to perform adequately or to follow agency policies, procedures, or instructions. . . . An ALJ cannot, however, be removed for any invidious reason or to influence the outcome in a particular adjudication." ${ }^{235}$ Francisco

232. United States v. Nixon, 418 U.S. 683 (1974).

233. 5 U.S.C. $\$ 1204$ (a)(1) ("The [MSPB] shall hear, adjudicate, or provide for the hearing or adjudication, of all matters within the jurisdiction of the Board under... any ... rule, or regulation...."). Nothing in the regulation distinguishes between the MSPB's appellate and original jurisdiction. Based on my research, the most common and long-standing way that the MSPB obtains jurisdiction via rule is through OPM regulations. See, e.g., Cowan v. United States, 710 F.2d 803, 805 (Fed. Cir. 1983).

234. 5 U.S.C. $\$ 7703(a)(1)$, (c).

235. SG Mem., supra note 101, at 9; see also Brief for Respondent Supporting Petitioners at 50, Lucia v. SEC, 138 S. Ct. 2044 (2018) (No. 17-130), 2018 WL 1251862, at*50. But does the solicitor general's interpretation mean that the agency could use removal to influence outcomes in more than one proceeding? 
continued that the "MSPB review [must be] suitably deferential to the determination of the Department Head." ${ }^{.236}$ In short, the solicitor general's view treats the ALJs as if their protections mirrored those for the civil service, where the MSPB merely defers to the agency's determination of cause, despite the statutory language requiring the MSPB to decide whether good cause exists in the first instance. ${ }^{237}$ Because the recommended impartiality regulations would treat all adjudicators like ALJs for removal purposes-the opposite of the solicitor general's proposed view-it is not necessary for the regulations to define "good cause." The MSPB's decisional law would continue to define the phrase. Moreover, with the MSPB determining whether cause exists, the impartiality regulations avoid the problem of allowing agencies to remove adjudicators based on inappropriate reasons under cover of vague criteria like "inadequate performance."

Finally, by replicating ALJs' protection from at-will removal for all adjudicators, the impartiality regulations prevent an administration from neutering the MSPB to render the removal protections ineffective. For much of the Trump administration, the MSPB has not been able to issue final orders because it has lacked either a quorum or all three members. ${ }^{238}$ The inability of the MSPB to function empowers employing agencies by fully limiting regular federal civil servants to appeal adverse actions. ${ }^{239}$ Given the Trump administration's professed hostility to civil service protections, the MSPB's failure to have a quorum may be one strategy to ensure that civil service law goes unenforced. ${ }^{240}$ But the same dynamic does not hold true for ALJs and, as proposed, for non-ALJ adjudicators. Agencies cannot act against adjudicators until the MSPB permits it to do so. By requiring the MSPB

236. SG Mem., supra note 101, at 9.

237. See supra note 88 .

238. See U.S. Merit Systems Protection Board: Frequently Asked Questions about the Lack of Board Quorum and Lack of Board Members, MERIT SySTEMS PROTECTION BOARD (Mar. 1, 2019), https://www.mspb.gov/FAQs_Absence_of_Board_Quorum_March_1_2019.pdf [https:// perma.cc/Y8TZ-CJZS] (discussing the functioning of the MSPB in light of its lack of a quorum).

239. See Adam Mazmanian, Senate Panel Advances Third MSPB Nominee, FCW (June 20, 2019), https://fcw.com/articles/2019/06/20/mspb-senate-quorum-mazmanian.aspx [https://perma. cc/UAN8-XHQ8] (noting that MSPB has a "backlog of more than 2,000 appeals"); Nicole Ogrysko, MSPB Has Never Been Without a Quorum for This Long, FED. NEWS NETWORK (Jan. 12, 2018), https://federalnewsnetwork.com/workforce-rightsgovernance/2018/01/mspb-has-neverbeen-without-a-quorum-for-this-long [https://perma.cc/523B-AP9J] (noting that civil servants cannot get backpay or reinstatement when the MSPB lacks a quorum).

240. See Ogrysko, supra note 239 (quoting federal employment attorney Debra D'Gostino as saying, "[ $\mathrm{t}]$ he board is all about enforcement of the Civil Service Reform Act, and I just can't see where this administration [is] interested in that act being enforced"). 
to act before adverse action, the impartiality regulations better protect adjudicator impartiality.

2. Merit-Based Appointment. Promulgating the removal provisions for the impartiality regulations addresses the agencyadjudicator dilemma. Yet, as recent executive practice indicates, the regulations can be much more comprehensive. They can also consider merit-based hiring and various indicia of separation of functions - all of which relate to impartiality. The recent executive order concerning ALJ hiring provides a starting point. Although the executive order listed only one minimal requirement for ALJ hiring-concerning bar licensure ${ }^{241}$-agencies have already set up thoughtful processes to consider germane skills and attributes for impartial ALJs. ${ }^{242}$

The impartiality regulations could go further by expressly requiring merit-based hiring for all agency adjudicators, subject to agencies' discretion to identify the relevant qualifications for their particular adjudicators. In Caperton v. A.T. Massey Coal, ${ }^{243}$ the Supreme Court required an elected state supreme court justice to recuse himself under the Due Process Clause when one party to an appeal had a "significant and disproportionate influence in placing the judge on the case by raising funds or directing the judge's election campaign when the case was pending or imminent." ${ }^{244}$ The problem was that the donor-party, even if indirectly, "ch[ose] the judge in his own case." 245

Agencies, in comparison, are frequently parties to agency adjudication, ${ }^{246}$ and they can often directly select their adjudicators. Recall that while agencies had long hired their ALJs under an OPMled merit-selection process that limited agency discretion to hire whomever the agency preferred, a recent executive order has removed

241. Exec. Order $13843 \S 3$ (July 10, 2018). The executive order did, however, list criteria that said ALJs "must display[:] appropriate temperament, legal acumen, impartiality, and sound judgment. They must also clearly communicate their decisions to the parties who appear before them, the agencies that oversee them, and the public that entrusts them with authority." Id. $\S 1$.

242. See JACK M. BEERMANN \& JENNIFER L. MASCOTT, RESEARCH REPORT ON FEDERAL AGENCY ALJ HiRING AFTER LUCIA AND EXECUTIVE ORDER 13843, at 30-45 (2019) (discussing interview-based findings of ALJ-hiring processes in numerous agencies, including DOL, HHS, NLRB, EPA, and FERC).

243. Caperton v. A.T. Massey Coal, Co., 556 U.S. 868, 870 (2009).

244. Id.

245. Id.

246. See Michael Sant'Ambrogio, Private Enforcement in Administrative Courts, 72 VAND. L. REV. 425, 446-50 (2019) (discussing types of agency adjudication). 
ALJs from the competitive service. Agencies may now directly hire ALJs without going through OPM's competitive ALJ-hiring process. ${ }^{247}$ Likewise, agencies can often appoint their non-ALJ adjudicators from already-hired agency officials. ${ }^{248}$ By requiring merit-based hiring and mandating that agencies consider the relevant criteria for hiring on the front end, agencies will have less ability to engage in partisan hiring, even if indirectly or sub rosa.

The concern over partisan-based hiring is not speculative. In 2018, The Washington Post reported that the White House rejected candidates for administrative judges on the Board of Veterans' Appeals ("BVA") based on the candidates' political orientation. The president, who has statutory authority to approve the Secretary of Veterans Affairs' appointments, ${ }^{249}$ required the candidates to list their political affiliations. The White House rejected the candidates affiliated with the Democratic Party and hired those affiliated with the Republican Party and one without a party affiliation who had voted in Republican primaries. Despite the fact that the Democratic-affiliated candidates were acting judges at the BVA and recommended by the Board's chairperson - an official whom President Trump appointedthe agency reopened the position to fill the remaining vacancies. ${ }^{250} \mathrm{In}$ the George W. Bush administration, the Department of Justice similarly engaged in partisan-based hiring of immigration judges and members of the Board of Immigration Appeals. ${ }^{251}$ Similar concerns over partisan hiring for immigration judges continue today. ${ }^{252}$

Just as the recent executive order has given agencies more discretion in ALJ hiring, the impartiality regulations could ensure that agencies use merit-based hiring for adjudicators. The impartiality regulations would not readopt the OPM's former merit-based hiring

247. See supra note 34 and accompanying text.

248. Barnett \& Wheeler, supra note 38, at 59-60, 60 fig. 20.

249. 38 U.S.C. $\$ 7101 \mathrm{~A}(\mathrm{a})(1)$ (2018).

250. Lisa Rein, "I've Never Seen These Positions Politicized": White House Rejection of Veterans Judges Raises Concerns of Partisanship, WASH. POsT (Oct. 23, 2018, 10:32 AM), https://www.washingtonpost.com/politics/ive-never-seen-these-positions-politicized-white-house -rejection-of-veterans-judges-raises-concerns-of-partisanship/2018/10/23/f488046a-ce51-11e8-920 f-dd52e1ae4570_story.html?noredirect=on\&utm_term=.5cbf107b2c46 [https://perma.cc/7VMT$\mathrm{KB} 6 \mathrm{~W}]$.

251. See Catherine Y. Kim, The President's Immigration Courts, 68 EMORY L.J. 1, 14-15 (2018) (describing the Department of Justice's inquiry into the partisan hiring of immigration judges during the George W. Bush administration).

252. Id. at 29 (describing concerns over the independence of immigration judges during the Trump administration). 
process for ALJs wholesale. To be sure, OPM, together with its predecessor, the Civil Service Commission, has more than a century of experience in merit-based hiring. But its ALJ-hiring process was widely criticized as too time-consuming and poorly designed. ${ }^{253}$ To work toward better merit-based hiring for neutral adjudicators specifically, the executive order and regulations could simply state as follows:

All adjudicators shall be selected, whether from outside or from within the agency, under a merit-based process. The agency shall consult the Office of Personnel Management and consider any recommendations from the Administrative Conference of the United States when establishing and revising the merit-based selection process for adjudicators.

This consultation-based approach permits agencies to have more control over the speed and overall design of the hiring process while promoting appropriate merit-hiring principles. Agencies have preferred various subject-matter and litigation-based expertise in ALJ hiring, ${ }^{254}$ and at least two agencies have sought to hire only those who have never worked at the agency to mitigate the appearance of proagency bias. ${ }^{255}$ Merit-based hiring helps ensure that the agency, despite directly choosing the judges in their own cases (as the Appointments Clause may require), considers only factors that are germane to the judge's ability to adjudicate fairly, efficiently, and competently. Ultimately, adjudicator hiring must not permit the return of a patronage system. Whatever ills patronage-based hiring has for the civil service in general, its dangers are most apparent for officials who are required to apply agency policy and statutory law neutrally, without favor to those who may or may not have supported the hiring administration and its policy goals.

3. Additional Provisions. ALJ hearings provide additional indicia of impartiality that are often absent in non-ALJ hearings. For instance, ALJs cannot have ex parte contacts with anyone about facts at issue and only certain, limited ex parte contacts regarding legal issues under

253. See, e.g., Michael Asimow, The Spreading Umbrella: Extending the APA's Adjudication Provisions to All Evidentiary Hearings Required by Statute, 56 ADMIN. L. REV. 1003, 1009 (2004); Nicole Schultheis, Executive Order Excepting Administrative Law Judges from the Competitive Service, RESUME PLACE (July 12, 2018), https://www.resume-place.com/2018/07/alj-exceptedfrom-competitive-service [https://perma.cc/7HLQ-SZLZ].

254. See, e.g., BEERMANN \& MASCOTT, supra note 242, at 30-45 (discussing the agencies' various qualifications, including subject-matter expertise and litigation experience).

255. See id. at 43, 44 (discussing the EPA and Federal Labor Relations Authority). 
the APA. ${ }^{256}$ Relatedly, they cannot prosecute or investigate for the agency or report to anyone who does. ${ }^{257}$ They also cannot receive performance reviews or bonuses from their agencies. ${ }^{258}$ Some non-ALJ adjudicators have all or some of these prohibitions, but some do not. ${ }^{259}$ The impartiality regulations could easily address these indicia in a way that promotes impartiality but also, like the provision on merit-based hiring, respects differences among agency adjudications.

Ex Parte Contacts. The impartiality regulations could contain a prohibition on ex parte contacts with agency adjudicators. Federal courts have recognized that ex parte communications can create due process problems by undermining the fairness of the proceedings. ${ }^{260}$ The APA has a complicated set of ex parte prohibitions that distinguishes between the kinds of communications, the identity of the decision-maker, and the nature of the agency proceeding. ${ }^{261}$ But the impartiality regulation can take a simpler approach for both ALJs and non-ALJ adjudicators - the one that ACUS's Model Adjudication Rules ("MARs") has proposed for more than twenty-five years in its MAR 120:

Except as required for the disposition of ex parte matters authorized by law, the Adjudicator may not consult a person or party on any matter relevant to the merits of the adjudication, unless on notice and opportunity for all parties to participate. This provision does not,

256. See 5 U.S.C. $\$ \S 554(d)(1), 557(d)$ (2018) (prohibiting certain ex parte communications).

257. See id. $\$ 554(\mathrm{~d})(2)$ (prohibiting supervision by investigative or prosecutorial agency officials); id. $\S 3105$ ("[ALJs] ... may not perform duties inconsistent with their duties and responsibilities as administrative law judges.").

258. Barnett, Against Administrative Judges, supra note 33, at 1655-56.

259. See Barnett \& Wheeler, supra note 38, at 61-66, 67-70, 73-83 (presenting survey data on the nature of limitations, if any, on non-ALJ adjudicators' ex parte communications). In my earlier study, my co-author and I reported that 14 percent of the identified types of non-ALJs who responded to the survey had no ex parte prohibitions. See id. at 68 fig. 25 .

260. Sierra Club v. Costle, 657 F.2d 298, 400 (D.C. Cir. 1981); see also U.S. Lines, Inc. v. Fed. Maritime Comm'n, 584 F.2d 519, 539 (D.C. Cir. 1978) ("The inconsistency of secret Ex parte contacts with the notion of a fair hearing and with the principles of fairness implicit in due process has long been recognized."); Appeal of Pub. Serv. Co., 454 A.2d 435, 441-43 (N.H. 1982) (holding that even in the absence of procedures by the legislature, due process requires state commission members to refrain from ex parte communications when they act in an adjudicative capacity).

261. See 5 U.S.C. $\$ 554(d)(1)-(2)$ (prohibiting ex parte communications concerning facts with anyone and limiting certain investigating or prosecuting employees from advising ALJs); $i d$. $\S 557$ (d) (prohibiting ex parte communications concerning the merits of the proceeding with those outside of the agency). 
however, preclude the Adjudicator from consulting with adjudicatory employees such as law clerks. ${ }^{262}$

Agencies could turn to MAR 120 and its additional provisionswhich govern agency heads, the timing of the prohibition, and remediation for violations-for additional considerations and guidance. Although many non-ALJ adjudicators are already subject to the standard provided in MAR $120,{ }^{263}$ a recent survey indicated that approximately 14 percent of the reported non-ALJ types-that is, identifiable groups of non-ALJs within an agency-have no limitations whatsoever on ex parte communications. ${ }^{264}$

Separation of Functions and Bonus Eligibility. Relatedly, the impartiality regulations could require separation of functions for all adjudicators, meaning that adjudicators can only adjudicate, not perform other agency functions. Agencies recently indicated that about 43 percent of reported non-ALJ-adjudicator types have no separation of functions, and about one-third of those types that preside over hearings in which an agency is a party also lack separation. ${ }^{265}$ MAR 121 calls for the same separation of functions that applies to ALJs to govern all agency adjudicators. ${ }^{266}$ The official comments to MAR 121 note that the APA excludes certain agency adjudications from the prohibition: those addressing initial licensing and those concerning rates, facilities, or practices related to public carriers or utilities. ${ }^{267}$

The separation of functions is especially important for non-ALJ adjudicators because, unlike ALJs, they are almost always subject to performance reviews ${ }^{268}$ and may receive performance bonuses from

262. Admin. CONF. U.S., Model AdJudicAtion Rule 120 (2018) [hereinafter MAR], https://www.acus.gov/sites/default/files/documents/Model\%20Adjudication \%20Rules\%209.13.1 8\%20ACUS_0.pdf [https://perma.cc/L4HE-P7GR ].

263. See Barnett \& Wheeler, supra note 38, at 68 (discussing the nature of ex parte limitations for non-ALJ adjudicators).

264. Id. at 68 fig. 25 .

265. Id. at 61 .

266. Compare MAR, supra note 262, at R. 121 (proposing that those doing investigative or prosecutorial work for the agency may not have any connection to adjudications or supervise the adjudicator), with 5 U.S.C. $\$ 554$ (d) (prohibiting employees from being supervised by someone in an investigative or prosecutorial role).

267. MAR, supra note 262, at R. $121 \mathrm{cmt} .2$.

268. See Barnett \& Wheeler, supra note 38, at 73 (noting that 99 percent of all 10,831 reported non-ALJ adjudicators were subject to performance appraisals). 
their agencies. ${ }^{269}$ The Supreme Court, although it has indicated that combined functions alone do not offend due process, ${ }^{270}$ has also repeatedly looked askance at adjudicators having a financial interest in the litigation before them. ${ }^{271}$ An agency-party paying its adjudicators bonuses may not create a direct interest in the outcome of the litigation, but doing so can indirectly, yet meaningfully, influence an adjudicator if she thinks that the agency will be more generous when she favors the agency. Similarly, impartiality regulations could delineate the appropriate considerations in reviewing non-ALJ adjudicators and in awarding non-ALJ adjudicators bonuses to mitigate any appearance of partiality.

Other matters may also be suitable for the impartiality regulations. For instance, ACUS has recommended that agencies adopt recusal processes and standards for agency adjudicators. ${ }^{272}$ Likewise, creating physical separation between agency adjudicators and the rest of the agency may be a meaningful way of maintaining psychological separation. ${ }^{273}$ The larger point is that impartiality regulations can address not only a constitutional dilemma of the Supreme Court's making but also other matters related to adjudicatory impartiality and fairness.

\section{Potential Concerns}

Impartiality regulations have drawbacks. They require resources, limit the responsibility that Congress and courts have in assuring that agency adjudication has legitimacy, and depend upon political will and long-sighted vision for good government. Each concern is addressed in turn below.

269. See id. at 77-78 (noting that 90 percent of all non-ALJ adjudicators are eligible for pay bonuses).

270. See Withrow v. Larkin, 421 U.S. 35, 54 n.20 (1975) (noting that the agency's internal separation of functions was not necessary to its holding that the particular sequence of functions at issue was constitutional).

271. See, e.g., Schweiker v. McClure, 456 U.S. 188, 196-97 (1982); Ward v. Monroeville, 409 U.S. 57, 60-62 (1972); Tumey v. Ohio, 273 U.S. 510, 520, 535 (1927).

272. Admin. Conf. U.S., Adoption of Recommendations, 84 Fed. Reg. 2139, 2139-41 (Feb. 6, 2019) (describing Recommendation 2018-4).

273. See Kristin E. Hickman, Symbolism and Separation of Powers in Agency Design, 93 NOTRE DAME L. REV. 1475, 1495-96 (2018) (discussing the use of physical separation in Canada to further separation of powers); Paul R. Verkuil, A Study of Informal Adjudication Procedures, 43 U. CHI. L. REV. 739, 787 (1976) (considering the utility of separated physical space to encourage separation of adjudicators from others in the agency). For findings on the status of physical separation for non-ALJs, see Barnett \& Wheeler, supra note 38, at 70-71. 
1. The Costs of Regulating Impartiality. Impartiality regulations, of course, have costs. The entire executive branch will need to invest time in drafting and circulating the executive order and promulgating the regulations. Aside from promulgation itself, impartiality has its own costs. Merit-based hiring is more demanding than discretionary hiring because it limits the pool of suitable candidates and requires some evaluation of the candidates' merit. The protection from at-will removal will render the removal of poorly performing adjudicators more onerous because of the required administrative process. Additional impartiality provisions may, in certain adjudications, slow down the hearing process by limiting ex parte contacts or limiting to whom the agency may assign adjudicatory roles.

Yet these costs are not as onerous as they may first appear. For instance, the promulgation costs are largely a one-time expenditure. Once drafted, any revisions to the order or regulations are likely to prove rare and be limited to only a handful of agencies because they address fundamental, structural matters related to adjudication, not fact-bound technical issues.

The protections from at-will discipline or removal only slightly alter the status quo. For ALJs, nothing changes. For non-ALJ adjudicators, the only change is that now the MSPB makes the initial determination as to whether good cause exists. Notably, these changes do not alter the entire civil service-merely a small portion of it. Depending on how the order and regulations define their covered adjudicators, at most they could cover around ten thousand of the 2.1 million federal employees, ${ }^{274}$ or less than one-half of a percent. Likewise, merit-based hiring is already required for the civil servicedespite room for improvement ${ }^{275}$-and agencies are already in the process of creating merit-based hiring processes. ${ }^{276}$

The additional hearing-related costs, such as ex parte prohibitions, will prove a more significant change to agency adjudication over the long term. But when weighing these benefits, two iterations of working groups that drafted ACUS's MARs-comprised of scholars, agency officials, and agency adjudicators-have included the provisions

274. CONG. RESEARCH SERV., R43590, FEDERAL WORKFORCE STATISTICS SOURCES: OPM AND OMB 1 (2019), https://fas.org/sgp/crs/misc/R43590.pdf [https://perma.cc/VV3N-SJF5].

275. See generally Barnett \& Wheeler, supra note 38, at 85-89 (suggesting improvements to non-ALJ hiring).

276. See generally BEERMANN \& MASCOTT, supra note 242, at 30-45 (discussing current ALJhiring processes). 
mentioned here. In fact, ACUS itself has recommended that agencies implement many of these protections proposed here to promote impartiality ${ }^{277}$ and many agencies have adopted certain protections. ${ }^{278}$ In short, I would be far from the first to find that the benefits of provisions that improve the appearance of impartiality outweigh the costs.

2. Shirking Congressional and Judicial Responsibility. One may be concerned that promulgating impartiality regulations lets courts and Congress off the hook by, respectively, giving them cover from the policy concerns of invalidating statutory provisions or failing to act to improve agency adjudication writ large. They may well do so. The impartiality regulations, to be clear, are a second-best response to my preferred outcome for the Court to bless the tiered protections from removal and for Congress to improve all adjudicators' appearance of impartiality. Because recent doctrinal shifts indicate that the Court is unlikely to adopt a functional approach to the president's removal power that accounts for due process concerns, ${ }^{279}$ the courts are unlikely to provide a solution. Likewise, Congress has proven fairly uninterested or ineffective in proactively protecting adjudicators. These branches' failure to act leaves the executive as the last, best option to protect adjudicatory impartiality.

But absent my preferred course, impartiality regulations can mitigate or moot judicial harm and serve as a replacement for congressional inaction. First, the impartiality regulations limit the ramifications of applying Free Enterprise Fund to adjudicators because the regulations, by replicating the statutory status quo, serve as a backstop. In fact, if agencies acted quickly to promulgate them before current judicial proceedings end, the regulations may moot any challenge because the Court's judgment would not lead to a remedy that changes anything. The adjudicators would have the same or more protection from at-will removal even absent the current statutory regime. Second, the regulations also help create a better system for non-ALJ adjudicators, who significantly outnumber ALJs, even if Congress fails to act or cannot act after a party's successful judicial

277. Admin. Conf. U.S., Recommendation 2016-4, at 1, 3-4 (Dec. 13, 2016), https://www.acus.gov/sites/default/files/documents/informal-agency-adjudication-recommendation -final.pdf [https://perma.cc/D49F-F7E5].

278. See Barnett \& Wheeler, supra note 38, at 60-84 (discussing the impartiality protections that agencies reported for non-ALJ adjudicators).

279. See supra note 25 and accompanying text. 
challenge based on Free Enterprise Fund. If Congress fails to or cannot address the issue, the regulations simply have the executive branch to do what it has historically done-regulate its own workforce.

An executive response does permit the other branches to avoid responsibility for a problem of their own making. But the executive has its own responsibility. It, no less than the other branches, should share the political accountability in creating and maintaining a legitimate bureaucracy. After all, as the executive's history of protecting the civil service indicates, the executive has the necessary tools to improve the federal bureaucracy. If the executive refrained from acting out of fear of shouldering the other branches' responsibilities, the executive would eschew its own duty.

3. The Necessity of Political Will. Finally, and perhaps most importantly in the near term, will the executive branch have any appetite for impartiality regulations? The inertia of and largely unlimited agency discretion under the current system may lead the executive branch to resist change. Given the Trump administration's views on removing ALJs as presented in Lucia and its aftermath, change would likely have to await an election, whether for a more receptive administration or as a lame-duck measure by an administration on its way out the door that is hostile to the incoming administration. But even new administrations of either major political party might see an advantage in being able to control adjudicators in matters that are important to them. For instance, conservatives may prefer to control immigration judges, while progressives may prefer to control adjudicators who preside over business-related enforcement proceedings. Or administrations of one political party may seek to establish impartial adjudicators only to have the administrations of the other political party undo the impartiality regulations to benefit its objectives. In other words, the "virtuous" party would lose policy battles to the "nonvirtuous" party - an untenable political position.

All of these concerns highlight an underlying imperative of my proposal: administrations of both major political parties must appreciate the long-term benefits that impartiality provides, and they must allow those benefits to outweigh their short-term partisan interests. Of course, impartiality can hinder an administration's shortterm policy goals. But unfettered control comes at a cost if meta policy goals are mistaken for policy applications in the course of an adjudication. For adjudications to have moral force they must apply, and at times develop, policies in a fair and evenhanded way. That moral 
force benefits everyone involved in adjudication by treating affected parties fairly, thus lending legitimacy to the process that, over time, can develop an agency's policy preferences. My hope is that this Article, past ACUS recommendations and MARs, and increased scholarly attention to adjudication will help provide the catalyst for agencies, policymakers, and regulated entities to focus on and articulate these benefits as part of improving agency adjudication.

If the executive branch has concerns over ceding significant control to impartial adjudicators, those fears are misplaced. ${ }^{280}$ Agencies have numerous basic, well-known tools for controlling policy and the legal principles that guide even impartial adjudicators: interpretive rules, substantive rules, policy statements, procedural rules, and influence on congressional statutory drafting. Indeed, these mechanisms provide more effective policy control because they apply to all relevant cases. The agency need not monitor individual adjudicators. And at any rate, brute policy implementation is not the only value that executive action should consider. Reasoned, openminded decision-making, protection of regulated parties' dignity interests, and decisions that inspire confidence in the public are all important aspects of good governance.

If my confidence in grand notions of good government and longterm interests of different actors seems naïve, I leave with you one reminder: The federal government encountered significant concerns over the impartiality of agency adjudicators during the New Deal. ${ }^{281}$ Congress and President Truman responded by giving ALJs-the agency adjudicators whom they expected to preside over nearly all evidentiary hearings ${ }^{282}$ - significant indicia of impartiality in the APA. To be sure, the action was in the form of statutory law, not executive action. But the APA provisions on impartiality came from the Franklin

280. Agencies do not always seek to control policy. For example, prior to the APA, the Interstate Commerce Commission ("ICC") gave its examiners near-total independence in certain matters, at least until the ICC's administrative appellate review: "No one in the Commission has power to substitute his judgment for that of the examiner in the preparation of the proposed report. If the examiner chooses to depart from all the precedents established by Commission decisions, he is free to do so and no one can stop him." 2 DAVIS, supra note 222 , 10.01 , at 2 (quotations omitted). But for certain other matters, the ICC reviewed the examiner's report before its issuance. See id. (describing ICC review of reorganization orders).

281. See Daniel J. Gifford, Federal Administrative Law Judges: The Relevance of Past Choices to Future Directions, 49 ADMIN. L. REV. 1, 6-8, 44 (1997) (discussing concerns over hearing examiners' combination of functions and bias).

282. See Barnett \& Wheeler, supra note 38, at 15 (citing APA legislative history and the attorney general's manual on the APA). 
D. Roosevelt administration's recommendations. ${ }^{283}$ The broader point is that our political system has recognized and addressed concerns over agency adjudicators' impartiality. And it can do so again.

\section{CONCLUSION}

The executive is not helpless to address the agency-adjudicator dilemma. Congress does not have to be the one to sheathe the Damocles Sword of at-will removal. The executive branch can find the scabbard all by itself. In fact, the executive can demonstrate its own power by voluntarily taking action, instead of demonstrating its weakness by having one of the other branches do so over the executive's objection. As this Article has indicated, the executive had long done so. This Article attempts to remind agencies that they have the power by themselves to limit the fallout from the constitutional competition between due process and Article II if the courts and Congress will not or cannot do so.

Perhaps even more importantly, the history of executive action in insulating certain officials demonstrates that the executive can act. The political responsibility falls not just on Congress but on the executive branch. The president cannot simply say that Congress or judicial doctrine ties his hands. Insulating or not insulating adjudicators is a political choice - a choice within the executive's discretion.

From a broader perspective, internal administrative law for adjudicatory independence brings needed and beneficial uniformity to federal agency adjudication. Professor Emily Bremer has persuasively argued that, contrary to the strong pull of uniformity for agency rulemaking and judicial review of agency action, "the governing norm in adjudication is exceptionalism." 284 Although exceptionalism may permit useful tailoring and efficiency, it has significant transparency costs and precludes the entrenchment and stability of norms across agencies. ${ }^{285}$ Because of its binary quality and the need for prophylactic action, impartiality is an especially suitable candidate for uniform treatment. The impartiality regulations here nudge agencies toward

283. See Gifford, supra note 281, at 7 (describing the history leading up to the APA's codification). Echoing the importance of recognizing good governance, the House Report for the APA expected "self-interest and due concern for the proper performance of public functions" to lead agencies to hire well-qualified adjudicators. H. REP. NO. 1980 (1946), reprinted in APA LEG. HISTORY, supra note 52, at 280.

284. Emily Bremer, The Exceptionalism Norm in Administrative Adjudication, 2019 WIS. L. REV. 1351, 1410.

285. See id. at 1413-16. 
uniformity, while giving some space for agency tailoring where necessary ${ }^{286}$ The executive need not await a congressional or judicial catalyst to provide useful uniformity, mitigate a constitutional conundrum, or improve the public's confidence in executive decisionmaking.

286. Kenneth Culp Davis argued more than sixty years ago that "[ $\mathrm{t}]$ he goal should be elimination of needless diversity, not the achievement of uniformity." 1 DAVIS, supra note 222, $\S 8.02$, at 520 . 